\title{
Copper-Zirconia Catalysts: Powerful Multifunctional Catalytic Tools to Approach Sustainable Processes
}

\author{
Nicola Scotti * ${ }^{\mathbb{D}}$, Filippo Bossola $\mathbb{D}^{\mathbb{D}}$, Federica Zaccheria and Nicoletta Ravasio $\mathbb{D}$ \\ CNR, Istituto di scienze e tecnologie chimiche "Giulio Natta” (SCITEC), via Golgi 19, 20133 Milano, Italy; \\ filippo.bossola@scitec.cnr.it (F.B.); federica.zaccheria@scitec.cnr.it (F.Z.); nicoletta.ravasio@scitec.cnr.it (N.R.) \\ * Correspondence: nicola.scotti@scitec.cnr.it; Tel.: +39-0250314384
}

Received: 13 December 2019; Accepted: 25 January 2020; Published: 1 February 2020

\begin{abstract}
Copper-zirconia catalysts find many applications in different reactions owing to their unique surface properties and relatively easy manufacture. The so-called methanol economy, which includes the $\mathrm{CO}_{2}$ and $\mathrm{CO}$ valorization and the hydrogen production, and the emerging (bio)alcohol upgrading via dehydrogenative coupling reaction, are two critical fields for a truly sustainable development in which copper-zirconia has a relevant role. In this review, we provide a systematic view on the factors most impacting the catalytic activity and try to clarify some of the discrepancies that can be found in the literature. We will show that contrarily to the large number of studies focusing on the zirconia crystallographic phase, in the last years, it has turned out that the degree of surface hydroxylation and the copper-zirconia interphase are in fact the two mostly determining factors to be controlled to achieve high catalytic performances.
\end{abstract}

Keywords: zirconia; copper; interphase; acid-base properties; DHC; methanol economy

\section{Introduction}

Zirconia-based oxides are receiving increasing attention from the scientific community as heterogeneous catalysts and supports for metal nanoparticles, owing to their tunable phase composition, redox, and acid/base properties. The combination between zirconia and copper is a fruitful union that leads to multifunctional catalysts showing high activity and selectivity in different classes of reaction and, in particular, in processes linked to methanol economy and (bio)alcohols upgrading. Such a wide range of applicability is due to the fact that these materials have relevant acid/base and redox properties, and they can also give spill-over and other interphase phenomena, coupled with the typical activity of the metal-supported catalysts [1-8]. Furthermore they have some advantages in terms of activity, stability, toxicity, and cost compared to materials based on precious metals, $\mathrm{ZnO}$, and/or mixed oxides. Despite being studied since from the beginning of the 1990s, the full potential of copper-zirconia catalysts has still to be exploited, while the reasons for their activity is still a matter of debate and some inconsistencies can be found in the literature, especially related with the zirconia polymorphs' features and activity. In this review, the properties and the main applications of copper-zirconia catalysts are critically analyzed, and the most impacting parameters on the catalytic activity are discussed.

\section{Preparation and Properties of Copper-Zirconia Catalysts}

Several parameters must be taken into consideration when preparing a copper-zirconia material. An attempt to sum up the main factors influencing the activity of the final material is provided in Figure 1.

Zirconia is employed in three different polymorphs (monoclinic, tetragonal, and cubic- $\mathrm{m}-\mathrm{ZrO}{ }_{2}$, $\mathrm{t}-\mathrm{ZrO}_{2}$ and $\left.\mathrm{c}-\mathrm{ZrO}_{2}\right)$, and also in an amorphous phase $\left(\mathrm{a}-\mathrm{ZrO}_{2}\right)$. The phase composition affects the acid-base and textural properties of the resulting material, and it can be tailored by thermal treatments 
and by the presence of other elements (e.g., $\mathrm{Si}, \mathrm{Y}, \mathrm{La}$ ). The structure-activity relationships of zirconia phases are controversial and not clearly understood, which is further complicated by the wide number of preparation techniques.

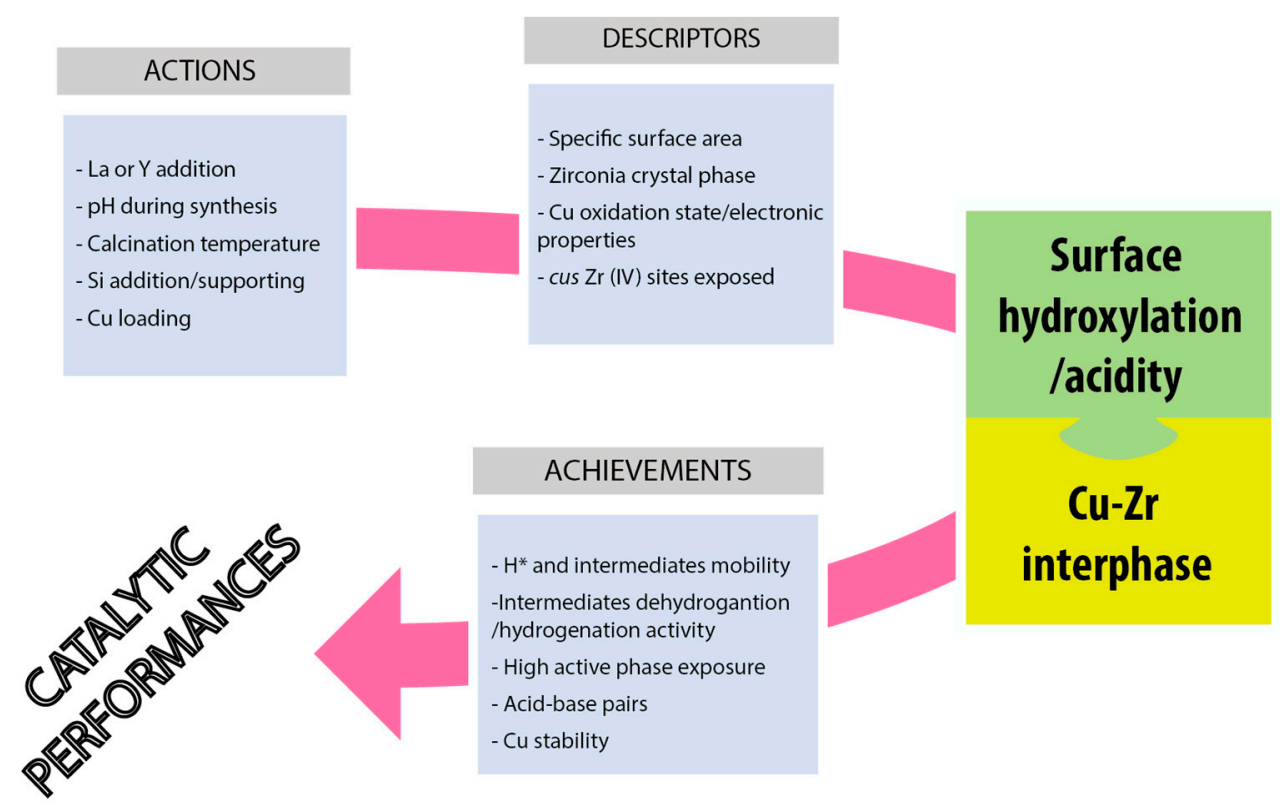

Figure 1. General guidelines for the preparation of an active copper-zirconia catalyst.

Tetragonal $\mathrm{ZrO}_{2}$ is the most frequently used, and it is often considered as the best choice in terms of acid properties and oxygen vacancies compared to the monoclinic $\mathrm{ZrO}_{2}$, but the results are not univocal [1,2,9-14]. On the other hand, amorphous zirconia, in spite of a non-crystalline nature, has a higher surface area, thus leading in several cases to a catalyst showing superior performances, as shown especially in some recent works $[2,4,5,15,16]$.

The properties of the zirconia polymorphs have been suggested to impact the copper dispersion and its oxidation state. It is reported that oxygen vacancies stabilize both $\mathrm{Cu}^{+}$cations and thermodynamically unstable tetragonal phase $[2,9,17]$, but some authors suggest that this kind of defect can be easily found also on monoclinic zirconia $[18,19]$. At the same time, it is reported that higher copper dispersion is reached over tetragonal zirconia, with some exceptions, especially in the case of high surface area amorphous $\mathrm{ZrO}_{2}[2,4,17-19]$.

The stabilization of $\mathrm{Cu}^{+}$is often invoked as crucial for the activity in some reactions $[2,9,20]$ being an acid site. However, some of us have recently described that even very small metallic copper and $\mathrm{CuO}$ nanoparticles can express an unusual acidity $[4,5,21,22]$, therefore moving on from the presence of $\mathrm{Cu}^{+}$.

The doping of zirconia is a strategy to improve several features. Ions with a valence lower than +4 (e.g., Y and La) favor the formation of oxygen defects [2,23-27], while $\mathrm{Si}$ is used to avoid the crystallization of $\mathrm{ZrO}_{2}$ at high temperatures to preserve the high surface area of the amorphous structure $[4,5,28]$. It is worth noting that most of the synthetic procedures reported in the literature involve the use of basic solutions, and involuntary silica contaminations might occur if carried out in classical lab glassware. Even a minimum amount of $S i$ is enough to drastically change the phase composition of the resulting $\mathrm{Zr}$ material. This may further complicate the rationalization of the results reported in the literature.

In conclusion, zirconia phase composition clearly has a dramatic effect on the catalytic behavior of the final material; however, actually, the effect cannot be rationalized or clearly explained. Despite the large number of studies on this topic, the only trend observed so far with a good approximation is that the better the $\mathrm{Cu}$ dispersion, the higher the activity of the catalyst. 
When preparing a copper-zirconia catalyst, two main general strategies may be adopted. The first one consists of the addition of the $\mathrm{Cu}$ during the step of zirconia preparation (e.g., co-precipitation and sol-gel methods). Typically, precursors of copper, such as copper nitrate, and zirconium, such as zirconyl chloride or nitrate, are combined to form the starting mixture; then, the procedures reported in the literature differ for temperature, $\mathrm{pH}$, aging time, precipitating agent, and/or additional metal/co-oxide precursors. In the second approach, copper is added after $\mathrm{ZrO}_{2}$ has been synthetized (e.g., impregnation techniques, chemisorption-hydrolysis). Sputtering [29] and grafting [30] methods have been also used with the aim of clarifying reaction mechanisms and active sites. The preparation method impacts the properties of the resulting materials, such as the dispersion of copper and on its phase composition.

In principle, co-precipitation techniques may be advantageous in terms of copper dispersion; however, some incorporation of $\mathrm{Cu}$ species into $\mathrm{ZrO}_{2}$ lattice occurs. On the one hand, this favors the formation of $\mathrm{Cu}^{+}$species, but it also results in a loss of active copper. Depending on the application, this effect is desirable or not [2,4,31,32].

Impregnation methods are simpler techniques that allow one to deposit copper on the surface of zirconia, limiting its incorporation into the lattice [2]. The control of the dimension of the particles and the nature of the copper phase can be achieved by tuning the properties of the preformed zirconia. With respect to the traditional impregnations, a better control on the copper phase might be achieved using some advanced methods [33], such as chemisorption-hydrolysis [5], metal vapor synthesis (MVS), chemical vapor deposition (CVD), or colloidal synthesis, but these protocols are poorly or not studied at all for the preparation of copper-zirconia catalysts.

The calcination is also a very critical step, because copper migrates and agglomerates thus compromising the catalytic performances [34] (Figure 2). This is particularly true for co-precipitation methods, in which the thermal treatment causes also the zirconia phase transformation.

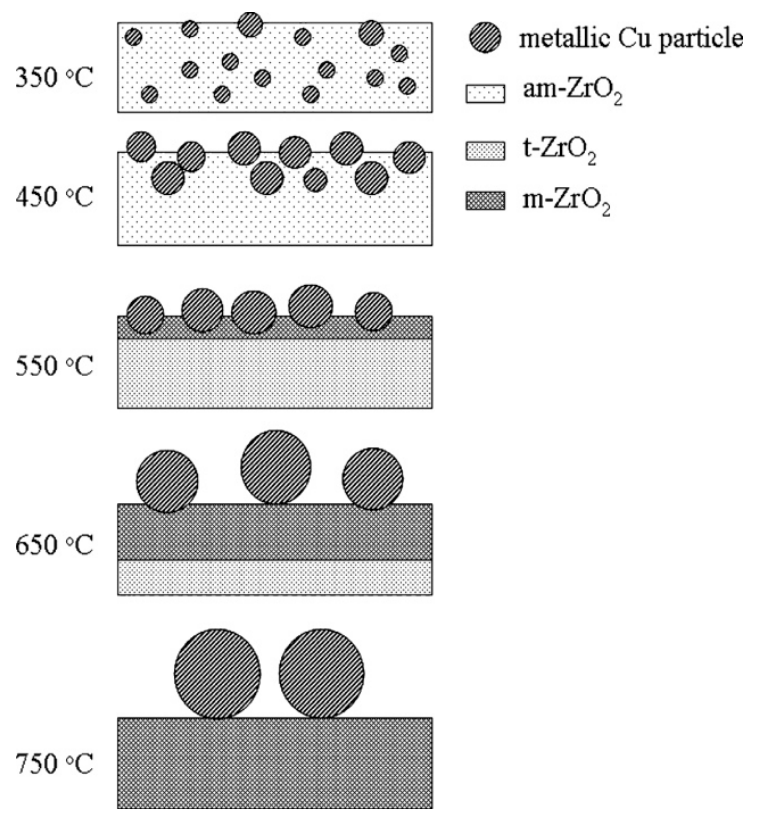

Figure 2. Schematic representation of the influence of the calcination temperature on the phase composition and copper particles size on a copper-zirconia material (https://pubs.acs.org/doi/10.1021/ jp075930k) [34]. Reprinted with the permission of the American Chemical Society (ACS); further permissions related to the material excerpted should be directed to the ACS.

A parameter that helps obtain a very finely dispersed copper phase is obviously the maximization of the surface area of the material. As previously mentioned, the use of amorphous zirconia is quite recent $[2,4,5,15,16]$ that allows, for example, synthetizing a catalyst with around $60 \%$ of dispersion and 
a final surface area of $216 \mathrm{~m}^{2} / \mathrm{g}$ (before copper deposition, it was $309 \mathrm{~m}^{2} / \mathrm{g}$ ) [4]. Promoters, such as ceria in $\mathrm{Cu}-\mathrm{Ce}-\mathrm{Zr}$ mixed systems, are also commonly used to maximize the copper dispersion for different applications [35-38].

Alongside the dispersion, a growing number of papers focus the attention on the $\mathrm{Cu}-\mathrm{Zr}$ interphase as the key aspect for obtaining highly active and selective copper catalysts with improved stability. Clearly, the interfacial area is linked with the dispersion of the copper phase [3,5,29,34,39-43].

The oxidation state of copper is a parameter that has to be controlled during the preparation of the catalyst or later, by performing a suitable pretreatment (e.g., reduction with $\mathrm{H}_{2}$ ) before the reaction. Depending on the application, one may need to stabilize $\mathrm{Cu}^{2+}, \mathrm{Cu}^{+}$, metallic copper, or mixed phases, even though that is not an easy task, in particular in the reaction medium. There is always a large debate on which is the oxidation state active in the reaction, alongside the fact that copper oxidation/reduction processes may occur easily during the reaction, making the understanding of the phenomena even more difficult $[4,5,9,14,19,27,44]$.

\section{Copper-Zirconia Catalysts for the Methanol Economy}

One of the most widespread uses of copper-zirconia catalysts is in the so-called sustainable methanol economy that includes several processes [6]. The reason is that metallic $\mathrm{Cu}$ has a density of the states with the top 3D band completely below the Fermi level, which makes it particularly suitable to interact with methanol ([45] and ref. therein). Other metals, such as Pd [46,47] or alloys [48], are as well active in methanol reactions, but their high cost makes $\mathrm{Cu}$ the undiscussed leader in this field.

Methanol synthesis (MS) (Equation (1)), also known as $\mathrm{CO}_{2}$ (or $\mathrm{CO}$ ) hydrogenation [49-52] and the hydrogen production via methanol steam reforming (MSR) (Equation (2)) [46,53-55], are among the most relevant reactions as they are directly involved in the framework of the $\mathrm{CO}_{2}$ valorization and the on-board hydrogen generation for transportation applications, respectively [6]. Methanol decomposition (MD) (Equation (3)) [56,57] is another reaction for the hydrogen generation, but it is sometimes is considered competitive of MSR and responsible for the poor $\mathrm{CO}_{2}$ selectivity.

The water gas shift reaction (WGS) (Equation (4)) and its reverse, namely the reverse water gas shift (RWGS), play a crucial role in controlling the CO selectivity in MS and MSR processes [55,58-60].

$$
\begin{array}{ccc}
\mathrm{CO}_{2}+3 \mathrm{H}_{2}=\mathrm{CH}_{3} \mathrm{OH}+\mathrm{H}_{2} \mathrm{O} & \mathrm{MS} & \Delta H_{298 \mathrm{~K}}=-49.7 \mathrm{~kJ} / \mathrm{mol} \\
\mathrm{CH}_{3} \mathrm{OH}+\mathrm{H}_{2} \mathrm{O}=\mathrm{CO}_{2}+3 \mathrm{H}_{2} & \mathrm{MSR} & \Delta H_{298 \mathrm{~K}}=+49.7 \mathrm{~kJ} / \mathrm{mol} \\
\mathrm{CH}_{3} \mathrm{OH}=\mathrm{CO}+2 \mathrm{H}_{2} & \mathrm{MD} & \Delta H_{298 \mathrm{~K}}=+90.2 \mathrm{~kJ} / \mathrm{mol} \\
\mathrm{CO}+\mathrm{H}_{2} \mathrm{O}=\mathrm{CO}_{2}+\mathrm{H}_{2} & \text { WGS } & \Delta H_{298 \mathrm{~K}}=-41.2 \mathrm{~kJ} / \mathrm{mol}
\end{array}
$$

Since MS and MSR are in principle the opposite of each other, and MD is often a side reaction in both processes, it is no surprise that a catalyst is active in all these reactions. Naturally, the same applies for copper-zirconia catalysts, and therefore, the output of a process will essentially depend on the feed and the reaction conditions. We will see though that the surface chemistry involved is quite different $[54,59,61,62]$, and many aspects of the catalysts can be tailored to maximize (or minimize) one or the other reaction.

Thus far, many strategies have been used to increase the activity of copper-zirconia catalysts in methanol applications, and much of the research efforts have been directed to identifying the active catalytic site(s) [41,56]. Unfortunately, little attention has been paid in trying to increase the stability of these systems that typically deactivate within a few hours due to $\mathrm{Cu}$ sintering [63-65].

$\mathrm{Cu}$ catalysts containing zirconia are generally more stable and produce less $\mathrm{CO}$ compared to $\mathrm{Zn}$-based ones in MSR reactions [53] and, as illustrated in a recent review by Din et al. [50], higher $\mathrm{CO}_{2}$ conversions can be obtained in the MS reaction because $\mathrm{CO}_{2}$ is more easily activated by the acid-base pairs of zirconia support. The reasons are many. First, the zirconia is highly reducible with the easy formation of $\mathrm{Zr}^{3+}$ species that allow for the hydrogen spillover [66], which is essential in MS [67], 
and these are able to bind the reaction intermediates, as pointed out by Kattel et al. [60] in a work that combines DRIFTS (diffuse reflectance infrared Fourier transform spectroscopy) and theoretical investigations. Second, compared to other systems such as $\mathrm{Cu} / \mathrm{SiO}_{2}$ [4], zirconia promotes the $\mathrm{Cu}$ reducibility in general, and specifically, $\mathrm{Cu}$ on $\mathrm{t}-\mathrm{ZrO} \mathrm{r}_{2}$ reduces at lower temperature than on $\mathrm{m}-\mathrm{ZrO}_{2}$. A good reducibility is critical to suppress the surface oxidation, as metallic $\mathrm{Cu}$ is the active center for the molecular hydrogen activation, in MS, or formation, in MSR and MD. Third, $\mathrm{Cu}^{+}$species, whose role in the reactions has been the specific object of several studies $[14,68,69]$, are not stable under reducing environment but can be stabilized by introduction into the zirconia lattice as they compensate for the negative charge of oxygen vacancies [70].

There has been quite a debate in the literature about which of these factors is the most impacting and how one influences the other. The fact that $\mathrm{Cu}$ dispersion should be as high as possible ([53] and ref. therein) is generally accepted, although there is no linear correlation with the activity [71]. Besides the obvious fact that the more Cu exposed, the higher the activity, Mayr et al. [29,42] have shown that is the interface between $\mathrm{Cu}$ and zirconia is what actually determines the "movement" of hydrogen species and, in the case of MSR, promotes the $\mathrm{CO}_{2}$ selectivity.

From the vast work by Bell and co-workers $[18,61,62,67,72]$ at the end of the 1990s, to the more recent investigations by Yang et al. [69] and Larmier et al. [41], just to cite but a few, great advancements have been made in understanding the complete picture of the surface chemistry during reactions with methanol. The main difference between methanol formation (MS) and hydrogen production reactions (MSR and MD) lays in the reactants, meaning that the first step of the catalytic process consists of the adsorption of $\mathrm{CO}_{2}$ (or $\mathrm{CO}$ ) and $\mathrm{H}_{2}$ in the former, and of methanol and water in the latter. The direct synthesis from $\mathrm{CO}_{2}$ of dimethyl ether (DME) is another reaction of particular interest, as DME can be a hydrogen vector for the on-board hydrogen generation via reforming [73]. Simple $\mathrm{Cu} / \mathrm{ZrO}_{2}$ catalysts do not have the necessary acidity to perform the dehydration of methanol though, and so more acidic materials are typically added, such as zeolites [74] or ferrierite [75]. The reader is referred to the dedicated literature for more insights on this reaction, as it will not be addressed in this review.

During MS, hydrogen is activated by the metallic $\mathrm{Cu}$, and indeed, the $\mathrm{CO}_{2}$ hydrogenation activity can be promoted by the addition of a second metal, such as $\mathrm{Ag}[76,77]$, which facilitates the $\mathrm{Cu}$ reducibility and metallic character. $\mathrm{CO}_{2}$ adsorbs on the zirconia and then is readily transformed into carbonates [62], while with CO, hydroxylated $\mathrm{Zr}$ sites adjacent to coordinatively unsaturated (cus) $\mathrm{Zr}^{4+}$ sites contribute to the adsorption, thus producing adsorbed formates (HCOO-Zr) [18]. There is a strong dependence between the polymorph of zirconia, the strength of adsorption, and the acid-base surface properties [9] (Figure 3). The $\mathrm{m}-\mathrm{ZrO}_{2}$ phase has been reported to adsorb more $\mathrm{CO}_{2}$ than the $\mathrm{t}-\mathrm{ZrO}_{2}$ because of the higher concentration of basic $\mathrm{O}^{2-}$ sites and cus $\mathrm{Zr}^{4+}$ Lewis acid sites. Hence, one might think that $\mathrm{m}-\mathrm{ZrO}_{2}$ is the most active in MS, just as reported by Bell and co-workers [18]. However, Samson et al. [9] have recently clarified why the highest methanol formation rates from $\mathrm{CO}_{2}$ are obtained with $\mathrm{t}-\mathrm{ZrO}_{2}$. This discrepancy can be ascribed to the different preparation procedures of the catalysts rather than to the specific crystallographic phase. A low-pH approach has been preferred by Bell and co-workers [18,61,62,67,72], whereas others have used precipitations $[14,64,72,78,79]$ at basic $\mathrm{pH}$. According to Samson et al. [9], such opposite preparation conditions result in significant differences in the surface hydroxylations and/or Lewis character of the final materials. They have also identified peculiar $\mathrm{Cu}$ species nearby oxygen vacancies, which are far more abundant on the (111) facet of the $\mathrm{t}-\mathrm{ZrO}_{2}$, and these are partly reduced to $\mathrm{Cu}^{+}$and act as electron acceptors-that is, Lewis acid centers.

On an industrial scale, methanol is produced from a $\mathrm{CO} / \mathrm{CO}_{2} / \mathrm{H}_{2}$ mixture [6], which is possible thanks to the activity of $\mathrm{Cu}$ in the WGS reaction that facilitates the conversion of $\mathrm{CO}$ into $\mathrm{CO}_{2}$. Interestingly, Grabow et al. [80] have shown via a series of theoretical calculations that the presence of $\mathrm{CO}$ in the mixture is in fact beneficial as it promotes the removal of $\mathrm{OH}^{*}$ species by RWGS reaction from the hydroxylated surface of the zirconia support. 


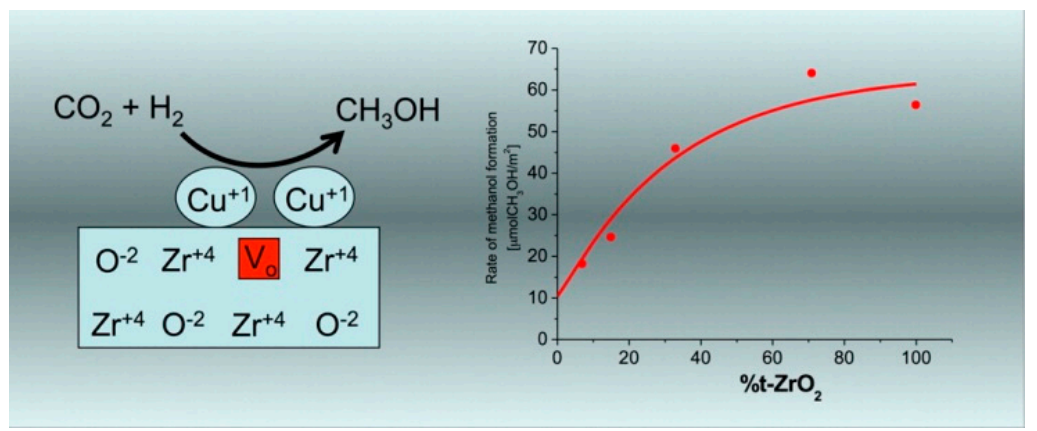

Figure 3. Effect of the percentage of $\mathrm{t}-\mathrm{ZrO}_{2}$ on the methanol synthesis rate [9] (https://pubs.acs.org/ doi/abs/10.1021/cs500979c). Reprinted with the permission of the American Chemical Society, further permissions related to the material excerpted should be directed to the ACS.

The key factor to be maximized for an active MS catalyst is the $\mathrm{Cu}$-zirconia interaction. Despite the higher concentration of oxygen vacancies in $\mathrm{t}-\mathrm{ZrO}_{2}$, Tada et al. $[2,81]$ reported as more selective to methanol a catalyst prepared on $\mathrm{a}-\mathrm{ZrO}_{2}$. They have used the incipient wetness preparation technique to avoid excessive $\mathrm{Cu}$ loss within the zirconia lattice by forming copper-zirconium mixed oxides $\left(\mathrm{Cu}_{\mathrm{x}} \mathrm{Zr}_{\mathrm{y}} \mathrm{O}_{\mathrm{z}}\right)$. This, along with the weaker adsorption of methanol on a- $\mathrm{ZrO}_{2}$ that suppresses the MD reaction, results in an active $\mathrm{Cu} / \mathrm{ZrO}_{2}$ with higher selectivity to methanol than those prepared on other polymorphs. Interestingly, the same authors have further developed the catalytic system by studying zirconia-silica mixed oxides $[30,82]$. They noticed that at the same $\mathrm{Cu}$ loading and similar morphological properties of the support, the presence of silica is highly beneficial to the catalytic activity and in particular to the methanol selectivity. This is somehow unexpected, as silica is a rather inert support in MS reaction. By means of an organometallic approach, the authors have prepared a series of silica supports on which isolated zirconium sites are grafted. Then, copper has been added again by grafting technique on the surface hydroxyl groups of the previously anchored zirconium sites. Upon reduction in hydrogen at $500{ }^{\circ} \mathrm{C}$, the so-obtained catalytic system consists of small copper nanoparticles $(2.6 \mathrm{~nm})$ with neighboring cus zirconium sites (Figure 4). Since the defects invoked for $\mathrm{Cu} / \mathrm{ZrO}_{2}$ catalysts [9] cannot form on such a system, i.e., oxygen vacancies, the source of the enhanced selectivity must be the $\mathrm{Zr}$ (IV) sites, as they assist the $\mathrm{CO}_{2}$ activation and hydrogenation of the intermediates. These findings imply that the amount of zirconia in the supports is not relevant, but rather it is the cus $\mathrm{Zr}$ (IV) sites exposed that act as Lewis acid centers.

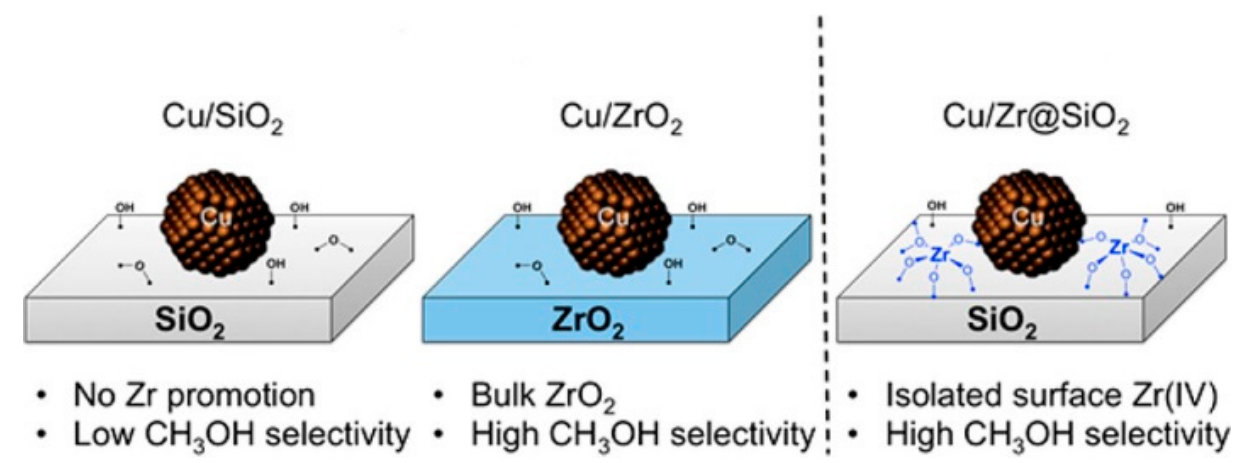

Figure 4. Experimental approach adopted by Tada and co-workers to understand the role of $\mathrm{ZrO}_{2}$ in $\mathrm{CO}_{2}$ hydrogenation [30] (https://pubs.acs.org/doi/10.1021/jacs.8b05595). Reprinted with the permission of the American Chemical Society, further permissions related to the material excerpted should be directed to the ACS.

A series of theoretical works have shed some light on the actual role of such interphases during the MS reaction. DFT calculations combined with XPS analyses had already revealed that $\mathrm{ZrO}_{2}$ works as a sort of buffer to accept or release electrons from or to the $\mathrm{Cu}$, which is partly oxidized [83,84]. 
On this so positively charged $\mathrm{Cu}$, which just for the sake of clarity must be in the form of very small nanoparticles or even clusters, the barrier of $\mathrm{H}_{2} \mathrm{O}$ dissociation is small, and the WGS reaction is enhanced [84]. Recently, Polierer et al. [85] have found that the interphase, although critical, is not the adsorption site of the reactants and intermediates during the $\mathrm{CO}_{2}$ hydrogenation. They have reported a volcano-shaped relation between the activity and the adsorption energy of various sites of a modelled $\mathrm{Cu} / \mathrm{ZrO}_{2}$ system (Figure 5). It is evident how $\mathrm{Cu}$ in close proximity to the interphase has the optimal adsorption energy - and in turn highest activity — whereas the interphase and other facets of $\mathrm{Cu}$ bind them too strongly or weakly, respectively.

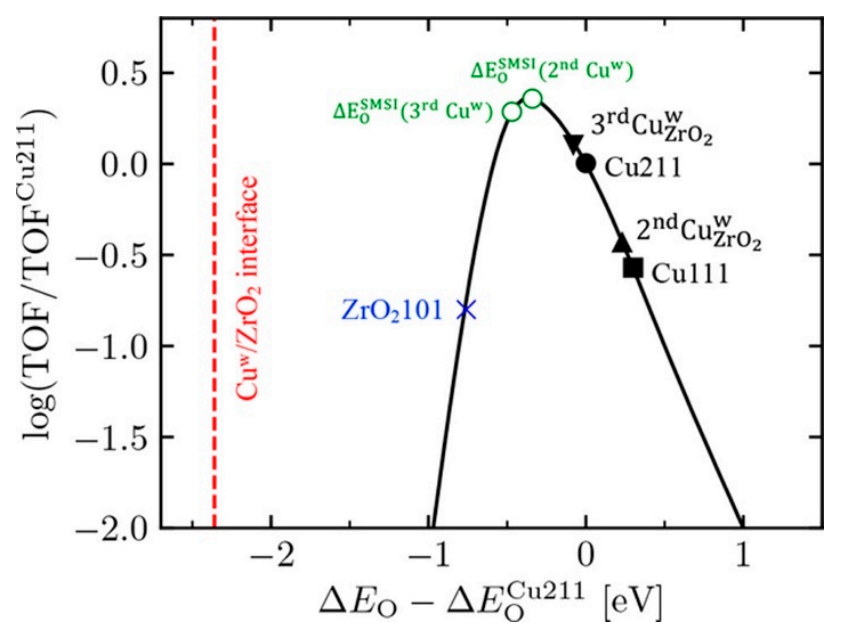

Figure 5. Theoretical activity volcano plot for the hydrogenation of $\mathrm{CO}_{2}$ to methanol [85]. (https: //pubs.acs.org/doi/10.1021/acs.jpcc.9b06500). Reprinted with the permission of the American Chemical Society, further permissions related to the material excerpted should be directed to the ACS.

However, there is still debate on which is the precise role of each site and on which reaction pathway is the most favorable $[52,60,85-87]$. Formate (HCOO) has been recognized in many studies as an intermediate during MS [88] and MSR alike (see below). The following hydrogenation to methanol is carried out by $\mathrm{H}$ and $\mathrm{OH}$ species spilling over toward the $\mathrm{Cu}$ phase. However, Kattel et al. [60] have calculated that over time, the formate species would poison the active sites and thus have proposed a reaction mechanism involving the RWGS reaction followed by $\mathrm{CO}$ hydrogenation through the formation of methoxy $\left(\mathrm{H}_{3} \mathrm{CO}\right)$ species as more likely.

Whichever the reaction pathway, these theoretical studies complete the overall picture at an atomic level of the $\mathrm{Cu} / \mathrm{ZrO}_{2}$ system for MSR reaction, whereby the interphase basically acts as a "bridge" between different catalytic sites. Therefore, a fine control over the $\mathrm{Cu}$ nanoparticles size and their interaction with the $\mathrm{ZrO}_{2}$ phase is key to achieving high catalytic performances [89].

The surface reactivity of MSR is a little different in the sense that the main reactions involved, besides the adsorption of the reactants, are the dehydrogenation and the molecular hydrogen formation. Again, metallic $\mathrm{Cu}$ is responsible for the latter [2,62], and without it, MD reactions would occur [61]. The dehydrogenation of the reaction intermediates is more complicated. From the works by Bell and co-workers $[18,61,62,67,72]$, it is known that methanol and water adsorb on the surface of zirconia as methoxy and -OH groups, respectively. Then, as reviewed by Yong et al. [54] and shown via DFT calculation by Lin et al. [90], they must travel all the way to the $\mathrm{Cu}$, and in particular to $\mathrm{Cu}^{+}$sites, where they are dehydrogenated to formates and to $\mathrm{CO}_{2}$. Indeed, the $\mathrm{CO}_{2}$ formation is the most delicate of the steps $[29,79,91]$, whereby most of the $\mathrm{Cu}$-based catalysts ([53] and ref. therein, [71,92]), including the commercial one [93], typically suffer from fairly high CO selectivity.

A straightforward strategy to promote the $\mathrm{CO}_{2}$ formation consists in working at low temperatures $\left(180-220^{\circ} \mathrm{C}\right)$ where the WGS reaction favors the conversion of $\mathrm{CO}$ to $\mathrm{CO}_{2}$. There are already some publications in this direction [93,94]. For instance, Azenha et al. [94] have described a quite active 
CuPd catalyst on $\mathrm{m}-\mathrm{ZrO}_{2}$ active at $180{ }^{\circ} \mathrm{C}$ (Figure 6). Alternatively, $\mathrm{CeO}_{2}$ is introduced into the zirconia support, due to its widely known oxygen storage capabilities, with good results in terms of CO suppression, such as those reported by Baneshi et al. [95] and Das et al. [96].
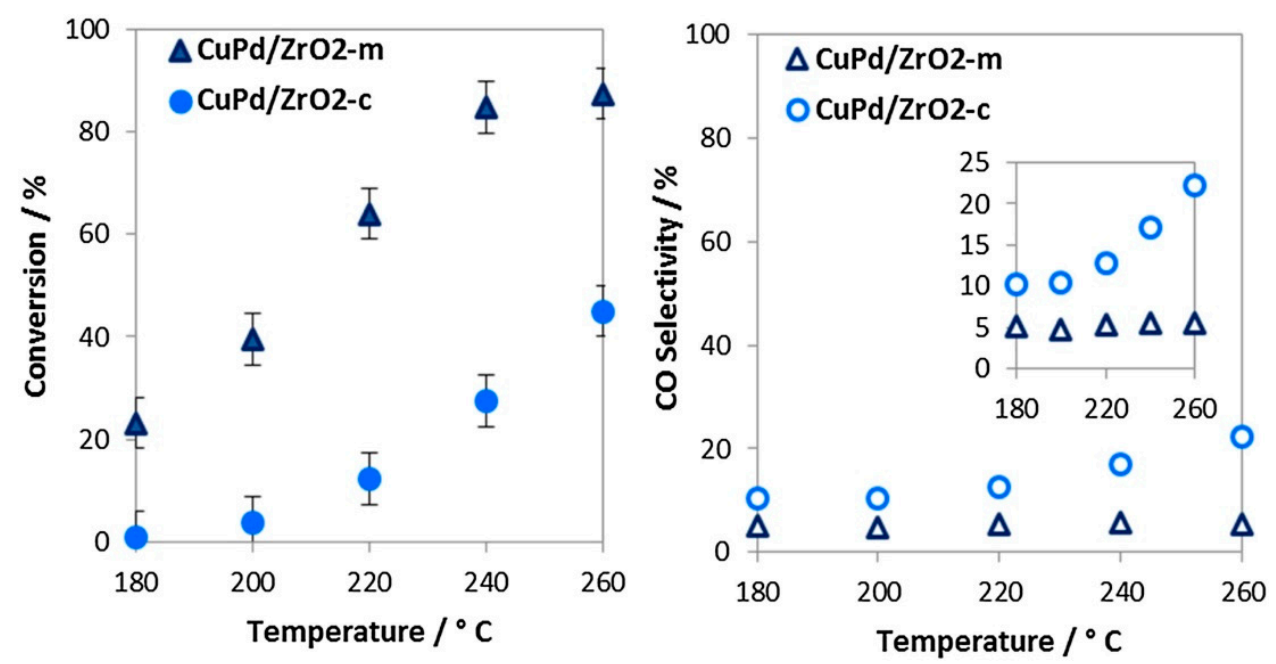

Figure 6. Cu-Pd catalysts on $\mathrm{c}-\mathrm{ZrO}{ }_{2}$ and $\mathrm{m}-\mathrm{ZrO}_{2}$ for low-temperature steam reforming of methanol [94]. Reprinted with the permission of Elsevier.

However, as pointed out by Mayr et al. [29,42], the factor most affecting the $\mathrm{CO}_{2}$ selectivity is the $\mathrm{Cu}-\mathrm{ZrO}_{2}$ interface. Therefore, $\mathrm{Cu}$ nanoparticles as small as possible are highly desirable, and indeed, the addition of zirconia to a $\mathrm{Cu} / \mathrm{ZnO}$ catalyst has been reported by Matsumura et al. [64] to decrease the $\mathrm{Cu}$ particle size with an increase in catalytic activity.

Smaller $\mathrm{Cu}$ nanoparticles with strong interaction with the support are useful to increase the stability of the catalysts during the reaction [63], and the preparation procedure can have a significant impact on the final $\mathrm{Cu}$ dispersion. For instance, Zhou et al. [14] have shown that by using a fractionated precipitation method to prepare a $\mathrm{Cu} / \mathrm{ZrO}_{2}$ catalyst, the $\mathrm{Cu}$ dispersion can be increased-although remaining low compared to other systems [4,97] — with a significant gain in stability.

Similar to the case of MS discussed above, the use of crystalline zirconia is limiting and a- $\mathrm{ZrO}_{2}$ with its higher surface area might be a better support in this sense. Lytkina et al. [98] and Wang et al. [34] have illustrated how the calcination temperature can impact on the zirconia support and in turn on the catalytic activity, indicating the $350{ }^{\circ} \mathrm{C}$ temperature as the maximum to avoid the zirconia crystallization and $\mathrm{Cu}$ sintering. Likewise, Yao et al. [71] have obtained a catalyst on a- $\mathrm{ZrO}_{2}$ with high $\mathrm{Cu}$ dispersion and high activity stable up to 50 hours by using an oxalate gel co-precipitation method.

The presence of $\mathrm{Cu}^{+}$sites has been for long considered necessary to the MSR reaction $[14,78,96,99,100]$, and Yang et al. [69] have clarified their decisive role in the dehydrogenation of the methoxy intermediates. Similar to the MS reaction, these sites basically act as Lewis centers [9]. However, there is an intrinsic limitation with the presence of both metallic $\mathrm{Cu}$ and $\mathrm{Cu}^{+}$, which is a splitting of the roles that results in an "effective" Cu participating to the overall reaction lower than the theoretical. Moreover, the fact that the adsorption sites and the reaction sites might be distant forces the adsorbed intermediates to travel onto the surface of the catalyst, thus slowing down the reaction and/or leading to side-reactions such as MD. Some of us [4] have developed a $\mathrm{Cu} / \mathrm{ZrO}_{2}$ catalyst modified with silica featuring electron-poor $\mathrm{Cu}$ nanoparticles that act both as adsorption centers for the methanol and as dehydrogenation sites with the zirconia contributing to the supply of -OH groups from the water activation. In this way, we obtained a 3.5 times higher hydrogen productivity compared to the parent $\mathrm{Cu} / \mathrm{ZrO}_{2}$ catalyst.

In conclusion of this section on the use of copper-zirconia catalysts in the methanol economy, it emerges that the comprehension of the reaction mechanisms, and how they are impacted by these 
catalysts, has made relevant steps forward. The efforts devoted to elucidating which of the crystal phases of the zirconia is more active in a specific reaction arrived at the conclusion that the surface acid-base properties, and to a lesser extent the oxygen vacancies, are by far more important factors. Metallic $\mathrm{Cu}$ is the active phase that is responsible for the molecular hydrogen formation (or activation), with the hydrogen species being transferred from (or to) the intermediates via the $\mathrm{Cu}^{+}$sites. The use of $\mathrm{a}-\mathrm{ZrO}_{2}$ with its high surface area, and its good interaction with $\mathrm{Cu}$ that maximizes the dispersion, looks the most promising catalytic system for methanol applications.

Further research is needed to elucidate the role of the specific acid-base species on the activity and how to optimize their population. For instance, Samson et al. [9] have shown how the MS activity is bound to the acidity, but the precise role of the Lewis and Brønsted species remains elusive. Since the acidity is so critical, tuning the electronic properties of the $\mathrm{Cu}$ nanoparticles might be an interesting tool to preferentially direct the reactions to more convenient pathways. Finally, more efforts must be devoted to the stabilization of the $\mathrm{Cu}$ phase. Small $\mathrm{Cu}$ nanoparticles have displayed longer activity than bigger ones, but they are still unfit for real applications. Dispersing the $\mathrm{Cu}$-zirconia phase on other supports, such as silica [97], might be an option. In Table 1, we summarize the catalytic behavior for the copper-zirconia catalysts reported in this review in MS and MSR.

Table 1. Comparison between the catalytic behavior for the copper-zirconia catalysts reported in this review in methanol synthesis (MS) and methanol steam reforming (MSR) reactions.

\begin{tabular}{|c|c|c|c|c|c|}
\hline Catalyst & Reaction & Preparation Procedure & Reaction Conditions & Catalytic Performances & Ref. \\
\hline $\begin{array}{c}\mathrm{Cu} / \mathrm{ZrO}_{2} \\
(80 \mathrm{wt} \% \mathrm{Cu})\end{array}$ & MSR & Co-precipitation & $\begin{array}{l}\mathrm{S} / \mathrm{C}=1.5 \\
\mathrm{~T}=250^{\circ} \mathrm{C}\end{array}$ & $\begin{array}{c}\text { Prod. } \mathrm{H}_{2}=400 \mathrm{mmol} \mathrm{gat}^{-1} \mathrm{~h}^{-1} \\
\text { Conv. }=-; \\
\text { Sel. } \mathrm{CO}<0.1 \%\end{array}$ & [78] \\
\hline $\begin{array}{l}\mathrm{Cu} /(\mathrm{t}-\text { and } \mathrm{m}-) \mathrm{ZrO}_{2} \\
(13 \mathrm{wt} \% \mathrm{Cu})\end{array}$ & MSR & $\begin{array}{l}\text { Microemulsion } \\
\text { technique }\end{array}$ & $\begin{array}{l}\mathrm{S} / \mathrm{C}=1.0 \\
\mathrm{~T}=250^{\circ} \mathrm{C}\end{array}$ & $\begin{array}{l}\text { Prod. } \mathrm{H}_{2}=-; \\
\text { Conv. }=57 \% \\
\mathrm{CO}=0.02 \text { vol. } \%\end{array}$ & [99] \\
\hline $\begin{array}{c}\mathrm{Cu} / \mathrm{ZrO}_{2} \\
(\mathrm{Cu} / \mathrm{Zr}=4 \mathrm{~mol} / \mathrm{mol})\end{array}$ & MSR & $\begin{array}{c}\text { Oxalate gel } \\
\text { co-precipitation }\end{array}$ & $\begin{array}{l}\mathrm{S} / \mathrm{C}=1.3 \\
\mathrm{~T}=260^{\circ} \mathrm{C}\end{array}$ & $\begin{array}{c}\text { Prod. } \mathrm{H}_{2}=350 \mathrm{mmol} \mathrm{g} \mathrm{cat}^{-1} \mathrm{~h}^{-1} \\
\text { Conv. }=100 \% ; \\
\mathrm{CO}=\text { trace amount }\end{array}$ & [71] \\
\hline $\begin{array}{c}\mathrm{Cu} / \mathrm{ZrO}_{2} / \mathrm{CeO}_{2} \\
(15 \mathrm{~mol} \% \mathrm{CuO})\end{array}$ & MSR & Co-precipitation & $\begin{array}{l}\mathrm{S} / \mathrm{C}=1.0 \\
\mathrm{~T}=220^{\circ} \mathrm{C}\end{array}$ & $\begin{array}{c}\text { Prod. } \mathrm{H}_{2}=0.38 \mathrm{mmol} \mathrm{g}_{\text {cat }}{ }^{-1} \mathrm{~h}^{-1} \\
\text { Conv. }=40 \% \\
\mathrm{CO}=-\end{array}$ & [91] \\
\hline $\begin{array}{c}\mathrm{Cu} / \mathrm{t}-\mathrm{ZrO}_{2} \\
(10 \mathrm{wt} \% \mathrm{Cu})\end{array}$ & MS & $\begin{array}{l}\text { Complexation with citric } \\
\text { acid }\end{array}$ & $\begin{array}{l}\mathrm{P}=80 \mathrm{bar} \\
\mathrm{T}=250^{\circ} \mathrm{C}\end{array}$ & $\begin{array}{c}\text { Prod. } \mathrm{MeOH}=632 \mathrm{mmol} \mathrm{g}_{\mathrm{cat}}{ }^{-1} \mathrm{~h}^{-1} \\
\text { Conv. }=15 \% \\
\text { Sel. } \mathrm{CO}=14 \%\end{array}$ & [9] \\
\hline $\begin{array}{l}\mathrm{Cu}_{1} \mathrm{Zr}_{0.5} / \mathrm{SiO}_{2} \\
(6.11 \mathrm{wt} \% \mathrm{Cu})\end{array}$ & MS & $\begin{array}{l}\text { Control Surface Reaction } \\
\text { (CSR) }\end{array}$ & $\begin{array}{l}\mathrm{P}=30 \mathrm{bar} \\
\mathrm{T}=250^{\circ} \mathrm{C}\end{array}$ & $\begin{array}{c}\text { Prod. } \mathrm{MeOH}=4 \mathrm{mmol} \mathrm{g}_{\mathrm{cat}}^{-1} \mathrm{~h}^{-1} \\
\text { Conv. = -; }\end{array}$ & [3] \\
\hline $\begin{array}{c}\mathrm{Cu} / \mathrm{a}-\mathrm{Zr}_{0.9} @ \mathrm{SiO}_{2} \\
(4.11 \mathrm{wt} \% \mathrm{Cu})\end{array}$ & MS & Grafting & $\begin{array}{l}\mathrm{P}=25 \mathrm{bar} \\
\mathrm{T}=230^{\circ} \mathrm{C}\end{array}$ & $\begin{array}{c}\text { Prod. } \mathrm{MeOH}=131 \mathrm{mmol} \mathrm{g}_{\text {cat }}{ }^{-1} \mathrm{~h}^{-1} \\
\text { Conv. }=-\% \\
\text { Sel. } \mathrm{CO}=-\%\end{array}$ & [30] \\
\hline $\begin{array}{l}\mathrm{Cu} / \mathrm{a}-\mathrm{ZrO}_{2} \\
(8 \mathrm{wt} \% \mathrm{Cu})\end{array}$ & MS & $\begin{array}{l}\text { Incipient } \\
\text { wetness }\end{array}$ & $\begin{array}{l}\mathrm{P}=10 \mathrm{bar} \\
\mathrm{T}=230^{\circ} \mathrm{C}\end{array}$ & $\begin{array}{c}\text { Prod. } \mathrm{MeOH}=1.4 \mathrm{mmol} \mathrm{g}_{\mathrm{cat}}{ }^{-1} \mathrm{~h}^{-1} \\
\text { Conv. }=-\% \\
\text { Sel. } \mathrm{CO}=-\%\end{array}$ & [81] \\
\hline $\begin{array}{l}\mathrm{Cu} / \mathrm{a}-\mathrm{ZrO}_{2}-\mathrm{SiO}_{2} \\
(13.7 \mathrm{wt} \% \mathrm{Cu})\end{array}$ & MSR & Incipient wetness & $\begin{array}{l}\mathrm{S} / \mathrm{C}=1.3 \\
\mathrm{~T}=260^{\circ} \mathrm{C}\end{array}$ & $\begin{array}{c}\text { Prod. } \mathrm{H}_{2}=370 \mathrm{mmol} \mathrm{g}_{\text {cat }}{ }^{-1} \mathrm{~h}^{-1} \\
\text { Conv. }=73 \% ; \\
\mathrm{CO}=\text { trace amount }\end{array}$ & [4] \\
\hline
\end{tabular}

\section{Copper-Zirconia Catalysts for the Dehydrogenative Coupling Reaction}

Thanks to the recent strong improvements in the bioalcohols production technologies, bioethanol and biobutanol are being produced in ever-increasing amounts from the fermentation of different biomasses-which is better if they are non-food ones [101-103]. Moreover, the use engineered micro-organisms is currently under research for the biological production (fermentation or biosynthesis) of higher alcohols from renewable sources, such in the case of bio-pentanol [104].

In this context, the reactions exploiting (bio)alcohols as starting materials are gaining always more scientific and technical importance to produce a large variety of added-value chemicals [101].

The acceptorless dehydrogenative coupling (DHC) is one of those reactions that allows one to directly transform two molecules of alcohol into the corresponding symmetrical ester, along with the production of two molecules of $\mathrm{H}_{2}$ (Scheme 1). It is a very attractive green strategy with a very high atom economy since the only "side product", that is hydrogen, can be easily recovered from the 
reaction. The traditional protocols for the preparation of esters on a large scale mainly rely on the use of the corresponding carboxylic acids and homogeneous catalysts, generating a significant amount of waste. The acid-catalyzed Fischer esterification is the most widespread example.

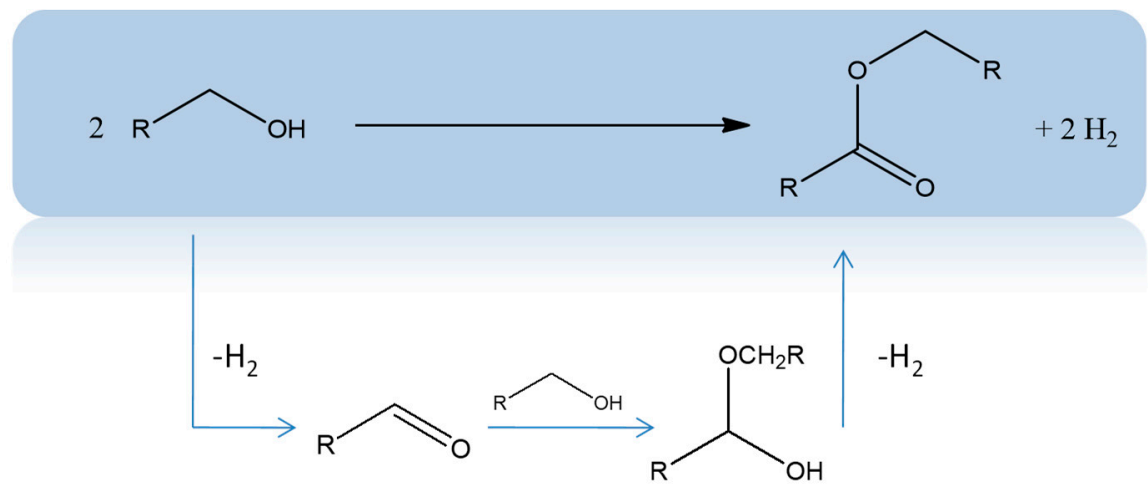

Scheme 1. Dehydrogenative coupling (DHC) process via hemiacetal route.

The DHC process involves sequential absorption/activation, dehydrogenation, and coupling steps. First, the alcohol has to be dissociatively adsorbed on the catalyst surface as alkoxide; then, by dehydrogenation, an aldehydic intermediate is formed. At the same time, hydride species are formed and generate molecular hydrogen. The activated aldehyde is prone to a nucleophilic attack of a second alcohol molecule to give the product of condensation (the hemiacetal). Finally, the dehydrogenation of the hemiacetal leads to the ester and the formation of a second $\mathrm{H}_{2}$ molecule (Scheme 1) [5,39,105].

This is the widely accepted mechanism operating over heterogeneous catalysts, whereas the alternative pathway of aldehyde dimerization (Tishchenko reaction) is rarely invoked [106,107].

Despite the attractiveness of the DHC process, few heterogeneous catalytic materials are present in the literature. One of the most studied systems is a complex multifunctional catalyst based on zirconia. This because the reaction requires the co-presence of acid-base pairs for the evolution and the coupling of the alcohol, and a metallic site for the hydride and molecular hydrogen formation. Hence, zirconia has to be coupled with a metal to design an active catalyst and, following the works published, copper seems to be its best partner.

One of the first works reporting the production of ethyl acetate from ethanol in significant yields is operated over a mixed Cu-Zr-Zn-Al system [108]. By performing the reaction feeding only acetaldehyde under $\mathrm{N}_{2}$ without observing the formation of ethyl acetate, the authors have strongly proved that the reaction proceeds though the hemiacetal route rather than via Tishchenko coupling. The catalytic system has been further improved by acting on the acid-base properties [109]. In particular, a treatment with an alkaline carbonate solution suppresses the acid sites formed upon reduction, which accounts for the formation of the by-products. The work emphasizes the need to control the acidity of the catalyst, but the characterization of the surface acid-base proprieties of the material prior and after the reduction is lacking. The effect of the basic treatment has been suggested by reactivity tests and by the analysis of the reaction products. However, the same authors have pointed to the role of acid site in favoring also the formation of ethyl acetate by promoting the hemiacetal intermediate. In principle, this means that the decrease in acidity should affect the formation of both the side product(s) and the desired ester. A better discussion on the specific role of the different acidic sites (Lewis and Brønsted) might be helpful in the interpretation of the results. In the same work, the authors have highlighted that the formation of the alkoxide is driven by basic sites by favoring the abstraction of the proton from ethanol. Only a following study shows the decisive effect on the ester formation of the basic sites [40], giving to them an even higher importance than the acid sites. Zirconia, bearing both acid and basic functionalities, promotes the formation of ethyl acetate when added as a mechanical mixture to a $\mathrm{Cu} / \mathrm{ZnO} / \mathrm{Al}_{2} \mathrm{O}_{3}$ or $\mathrm{PdO} / \mathrm{m}-\mathrm{ZrO}_{2}$ catalyst. The interphase between the $\mathrm{Cu}$ - or Pd-based catalyst 
and $\mathrm{ZrO}_{2}$ is extremely relevant for spillover phenomena-that is, the migration of the active species between the two catalytic surfaces.

The zirconia phase has also a great influence on the oxidation state of copper, together with the catalyst preparation method, but a clear trend in this respect is difficult to be define because, as already discussed previously, too many variables are involved, such as the use of additives, dopants or co-oxides, a specific calcination temperature, and reduction procedure.

Often, a copper phase with the co-presence of multiple oxidation states $\left(\mathrm{Cu}^{+}\right.$and $\left.\mathrm{Cu}^{0}\right)$ is found to be present after a reduction treatment $[19,110]$. This is only the starting point, which could easily evolve during the reaction. The oxidation state of copper and its catalytic implications are not of easy understanding, and it is often a matter of large debate. Indeed, some authors have shown that the proper combination of $\mathrm{Cu}^{+}$and $\mathrm{Cu}^{0}$ a- $-\mathrm{ZrO}_{2}$ or $\mathrm{m}-\mathrm{ZrO}_{2}$ is beneficial for the DHC reaction [19] but, at the same time, a Cu${ }^{2+}$-based catalyst $\left(\mathrm{CuO} / \mathrm{ZrO}_{2}\right)$ has been found to be extremely active [5], as well as one featuring metallic copper [3].

It is acknowledged that between $\mathrm{Cu}$ and $\mathrm{Zr}$, a great interaction is established, especially when high surface area and/or amorphous zirconia is used. This strong interaction drives the metal dispersion, its reducibility, and the formation of $\mathrm{Cu}-\mathrm{Zr}$ interphase properties that can be properly exploited to design very active catalysts. The interaction between copper and zirconia can be investigated through TPR (temperature-programmed reduction) analysis, whereby small $\mathrm{Cu}$ nanoparticles in strong interaction with the support reduce easier than larger and less-interacting aggregates $[4,5,19,56,71,99,111-115]$.

An attempt to provide a direct correlation between interfacial $\mathrm{Cu}-\mathrm{Zr}$ sites and the activity of these materials in ethyl acetate synthesis has been made by preparing catalysts with a different $\mathrm{Zr}$ loading starting from a common benchmark of $\mathrm{Cu} / \mathrm{SiO}_{2}$ [3]. Moderate ester selectivity has been obtained only in the presence of accessible $\mathrm{Cu}-\mathrm{Zr}$ entities, but the work does not address the nature of the active site.

The cooperative role of copper and zirconia in the $\mathrm{DHC}$ reaction has been further elucidated through the absorption of 1-butanol over $\mathrm{CuO} / \mathrm{ZrO}_{2}$ and $\mathrm{ZrO}_{2}$ surfaces [5]. The FT-IR analyses have shown that the alkoxide is formed on the zirconia, but its further transformation occurs only in the presence of copper. The reported catalyst that exploits a commercial high-surface area a- $\mathrm{ZrO}_{2}$ is highly active and selective thanks to a high $\mathrm{Zr}-\mathrm{Cu}$ interdispersion that ensures an elevated presence of active sites. Indeed, the reaction occurs on the acid-base pairs, formed by $\mathrm{CuO}$ Lewis acid sites [21,22] and $\mathrm{ZrO}_{2}$-based strong basic sites (Figure 7). A yield of $87 \%$ of ethyl acetate has been obtained in a solvent-less, gram-scale reaction. By using other linear aliphatic alcohols, an even higher yield has been achieved [5].

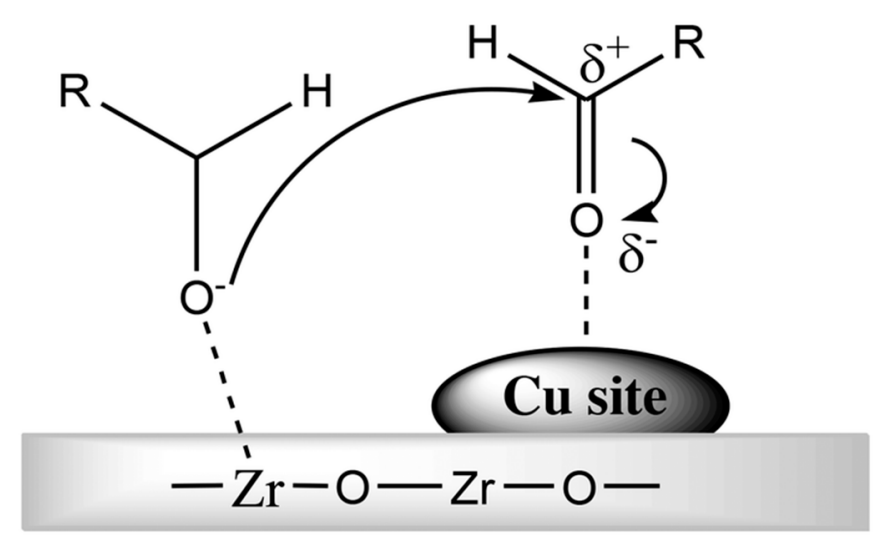

Figure 7. Suggested active site for the $\mathrm{DHC}$ reaction in which the acid-base pair is formed by a $\mathrm{CuO}$ Lewis acid site and $\mathrm{ZrO}_{2}$-based strong basic site. $\mathrm{CuO}$ promotes the dehydrogenation of the alcohol and activates the aldehyde towards the attack of a second alcohol molecule activated by the basic sites of $\mathrm{ZrO}_{2}$ [5]. Reproduced by permission of The Royal Society of Chemistry. 
A strong relationship between acid-base pairs and ester yield has been found in a series of copper-based catalysts in which $\mathrm{Cu} / \mathrm{ZrO}_{2}$ stands out for both the investigated parameters [39] (Figure 8). For comparison, the material of the series with the highest number of acid sites, that is the $\mathrm{Cu} / \mathrm{Al}_{2} \mathrm{O}_{3}$, shows an ester yield below $10 \%$, while on $\mathrm{Cu} / \mathrm{ZrO}_{2}$ it is more than $70 \%$. In this case, the site for the reaction is suggested to be constituted by surface acid-base pairs with adjacent metallic $\mathrm{Cu}$ species, acting in a synergistic way. Thus, differently to what some of us reported [5], the authors ascribed to copper phase only the dehydrogenation activity and not the acidic one.

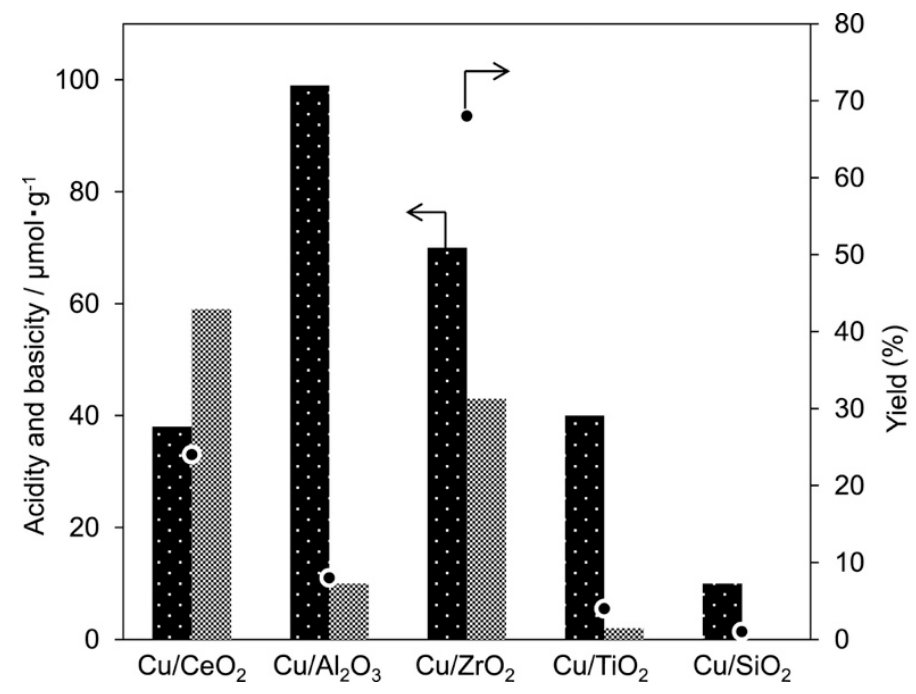

Figure 8. Relationship between the amount of acid (white squares with black background) and base (chessboard pattern) of different catalysts and their octyl octanoate yield (•) [39] (https://pubs.acs.org/ doi/10.1021/acsomega.7b01142). Reprinted with the permission of the American Chemical Society; further permissions related to the material excerpted should be directed to the ACS.

Few examples on the use of metals others than copper have been reported for the acceptorless DHC reaction [105,116-118]. However, the strong synergy between $\mathrm{Cu}$ and $\mathrm{Zr}$ has become even more clear with the testing of different supported $\mathrm{ZrO}_{2}$ materials: $\mathrm{Co}, \mathrm{Ni}, \mathrm{Ru}, \mathrm{Pd}, \mathrm{Ag}$, Ir, or Pt catalysts have all exhibited lower activity and selectivity compared to $\mathrm{Cu}$ [39].

The high activity of the $\mathrm{Cu} / \mathrm{ZrO}_{2}$ systems makes it unsuitable when highly reactive aromatic alcohols are used. This is because the rapid formation of the aldehyde limits the amount of the alcohol available for the coupling reaction to form the hemiacetal; thus, a limited ester yield can be obtained [39]. For comparison, a $\mathrm{Cu} / \mathrm{CeO}_{2}$ catalyst with a moderate activity in alcohol dehydrogenation has a higher yield of ester on aromatic substrates.

The heterogeneously catalyzed DHC reaction has been studied in particular for the synthesis of linear ester from ethanol and also from different bioalcohols, as they are (always) easily available. This process can be also used for the construction of $\mathrm{C}-\mathrm{O}, \mathrm{C}-\mathrm{N}, \mathrm{C}-\mathrm{S}, \mathrm{C}-\mathrm{C}$, and $\mathrm{C}=\mathrm{C}$ bonds and cyclic compounds, such as lactones [119,120], especially over Pd, Pt, or Ru catalytic systems, different from the $\mathrm{Cu}-\mathrm{Zr}$ duo.

To the best of our knowledge, despite the improvements in the DHC processes and the promising applications on the large scale, they still remain in the lab-scale research, and no industrial use is currently operating. In Table 2, we summarize the catalytic behavior for the $\mathrm{Cu}$-, $\mathrm{Zr}$-based catalysts in DHC reaction. 
Table 2. Comparison between the different $\mathrm{Cu}-$, Zr-based catalysts in DHC reaction.

\begin{tabular}{cclcccc}
\hline Catalyst & Substrate & Condition & $\mathbf{T ~}\left({ }^{\circ} \mathbf{C}\right)$ & $\mathbf{C ~ ( \% )}$ & $\mathbf{S ~ ( \% )}$ & Ref. \\
\hline $\mathrm{Cu}-\mathrm{Zn}-\mathrm{Zr}-\mathrm{Al}-\mathrm{O}$ & Ethanol & Gas phase & 240 & 82 & 76 & {$[108]$} \\
$\mathrm{Cu} / \mathrm{m}-\mathrm{ZrO}_{2}$ & Ethanol & Gas phase & 300 & 49 & 81 & {$[19]$} \\
$\mathrm{Cu} / \mathrm{m}-\mathrm{ZrO}_{2}$ & Ethanol & Gas phase & 200 & 45 & 73 & {$[100]$} \\
$\mathrm{Cu} / \mathrm{ZrO}{ }_{2} / \mathrm{Al}_{2} \mathrm{O}_{3}$ & Ethanol & Gas phase & 260 & 86 & 71 & {$[121]$} \\
$\mathrm{Cu} \mathrm{Zr}_{0.25} / \mathrm{SiO}_{2}$ & Ethanol & Gas phase & 200 & 30 & 33 & {$[3]$} \\
$\mathrm{Cu}-\mathrm{Zn}-\mathrm{Zr}-\mathrm{Al}-\mathrm{O}$ & Ethanol & Gas phase & 220 & 66 & 85 & {$[99]$} \\
$\mathrm{Cu} / \mathrm{a}-\mathrm{ZrO} 2$ & Ethanol & Batch & 250 & 89 & 98 & {$[5]$} \\
$\mathrm{Cu} / \mathrm{a}-\mathrm{ZrO} 2$ & 1-butanol & Batch & 250 & 98 & 100 & {$[5]$} \\
$\mathrm{Cu} / \mathrm{m}-\mathrm{ZrO}$ & 1-octanol & Batch & 170 & 99 & 68 & {$[39]$} \\
$\mathrm{Cu}-\mathrm{Zn}-\mathrm{Zr}-\mathrm{Al}-\mathrm{O}$ & 1,4-butanediol & Gas phase & 240 & 84 & 98 & {$[110]$} \\
\hline
\end{tabular}

\section{Challenges and Perspectives}

Copper-zirconia are extremely versatile and tunable materials. Redox and acid-base properties can be controlled by the right combination of zirconia and copper, leading to a multifunctional catalyst. Due to the complexity of the system, which is simple only in its appearance, different parameters must be controlled during the synthesis, making a comparison and a systematic rationalization of its properties fairly hard.

Table 3 tentatively lists the main milestones on the comprehension of the copper-zirconia systems by using methanol economy-related reactions and the DHC reaction as case histories.

Table 3. Significant advances in the comprehension of copper-zirconia catalysts (MS = methanol synthesis; $\mathrm{MSR}=$ methanol steam reforming; $\mathrm{MD}=$ methanol decomposition; $\mathrm{DHC}=$ dehydrogenative coupling reaction)

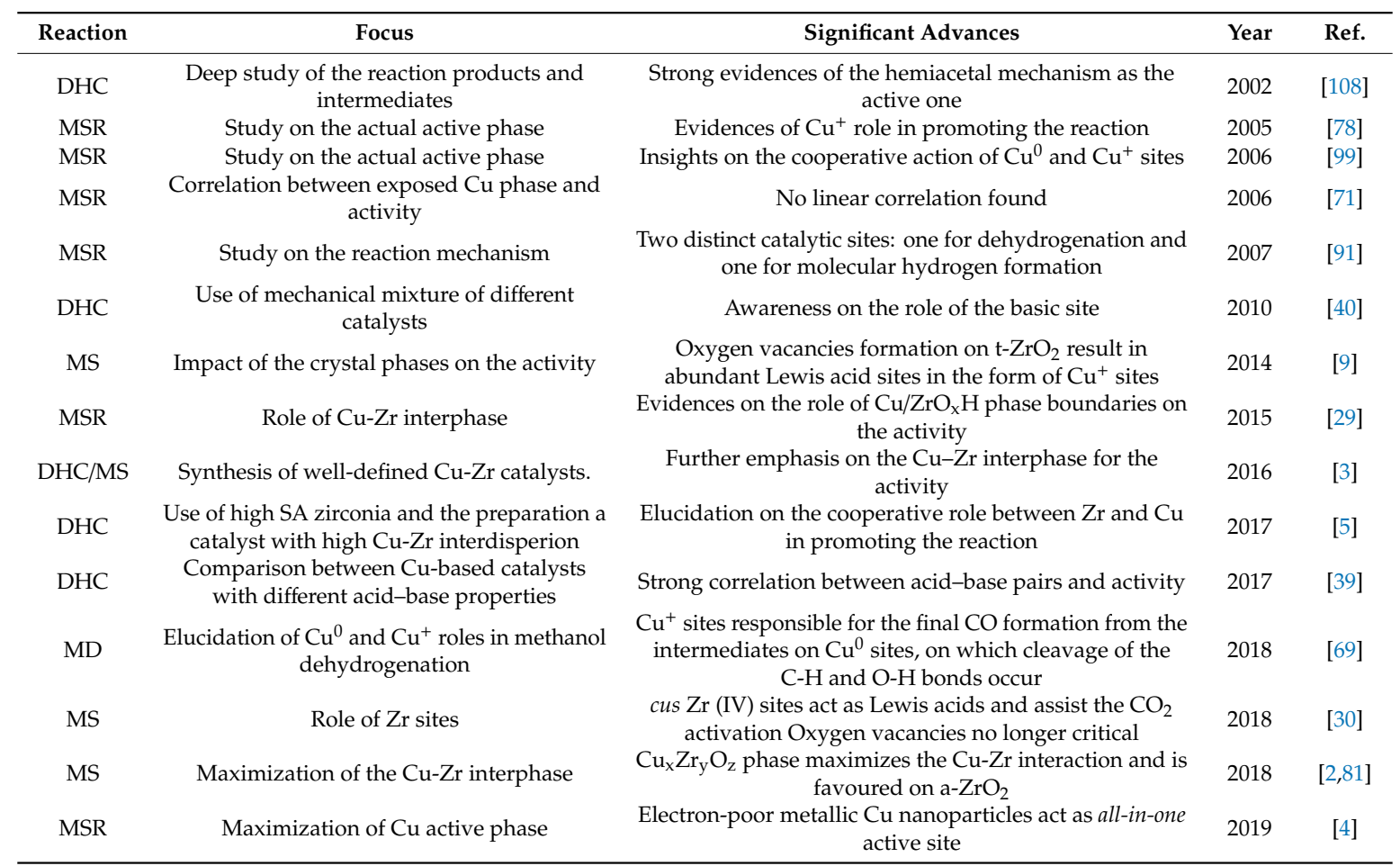

The extensive and systematic study carried out so far has undoubtedly deepened our understanding of such systems in the two broad fields discussed in this review. Reaction mechanisms have been linked to the actual catalytic sites present under reaction conditions, eventually identifying the most relevant descriptors of the overall process. These insights are revealing to be precious for the 
exploitation of copper-zirconia catalysts in new fields owing to multifunctionality. One example is the transformation of substrates derived from cellulose or hemicellulose, such as levulinic acid and $\gamma$-valerolactone $[8,31,43,44,122-126]$, which is certainly an emerging trend due to the need to improve the efficiency and the sustainability of the transformation routes of lignocellulose valorization for the production of strategic platform molecules and valuable compounds.

More in detail, after many years of research, it turned out that the most impacting aspects of the copper zirconia catalysts are two: the copper exposure, and hence the copper-zirconia interphase, and the zirconia surface hydroxylation degree, which is tightly connected to the acid-base properties. Their optimization has direct implications on the surface hydrogen and intermediates mobility and on the electronics and stability of the copper phase. High surface area zirconia, with the a- $\mathrm{ZrO}_{2}$ being highly promising, and high amounts of exposed cus $\mathrm{Zr}$ (IV) sites, that act as Lewis centers and therefore help hydrogenating/dehydrogenating the intermediates, are effective tools to achieve high catalytic activity (Figure 1). The role of the oxygen vacancies seems to be less critical than what was once believed and mainly consists in promoting the $\mathrm{Cu}^{+}$formation. Their population depends on the crystallographic phase and the presence of the proper dopant.

The high activity of $\mathrm{ZrO}_{2}$ in catalytic transfer hydrogenation reactions [127-129] makes it a powerful means for the development of $\mathrm{H}_{2}$-free cascade processes in the biorefinery scenario, and the combination with copper allows the design of innovative multifunctional materials. In this sense, the versatility of zirconia-based catalysts is evident in the methanol synthesis whereby $\mathrm{ZnO}$ can convert only $\mathrm{CO}_{2}$, whereas the acid-base pairs of $\mathrm{ZrO}_{2}$ permit also the hydrogenation of $\mathrm{CO}$ [52].

Copper-zirconia are also systems with low environmental impact. The European Medicine Agency classification shows how copper has very low toxicity with respect to noble metals and $\mathrm{Ni}$, while $\mathrm{ZrO}_{2}$ is considered to be a safe material [130,131].

The most significant drawbacks still hampering the implementation on the industrial scale are the fine control over the phase composition of the zirconia, with relevant consequences on both the availability and stability of the copper phase, and the precise tuning of the acid-base properties, which is still quite elusive. All this is further complicated by the fact that typically zirconia-base materials have a dynamic behavior under reaction conditions, such as copper aggregation, loss, and/or changes in its oxidation state, making the overall stability of the catalyst the first issue that still requires effective answers.

\section{Conclusions}

Even though the comprehension of copper-zirconia systems has reached a deep level and the catalysts have shown high activity in the methanol economy, in our view, their full potential is still to be exploited, especially as far as the transformation of biomass-derived platform molecules to high added-value products is concerned. In this sense, new applications are growing, especially for what concerns the valorization of the platform molecules that derive from lignocellulose stream, but these still remain largely unexplored fields.

Author Contributions: Conceptualization, N.S. and F.B.; Writing-Original Draft Preparation, N.S. and F.B.; Writing-Review and Editing, N.R. and F.Z. All authors have read and agree to the published version of the manuscript.

Funding: This research received no external funding.

Conflicts of Interest: The authors declare no conflict of interest. 


\section{References}

1. Lee, H.J.; Kang, D.C.; Pyen, S.H.; Shin, M.; Suh, Y.W.; Han, H.; Shin, C.H. Production of $\mathrm{H}_{2}$-free CO by decomposition of formic acid over $\mathrm{ZrO}_{2}$ catalysts. Appl. Catal. A Gen. 2017, 531, 13-20. [CrossRef]

2. Tada, S.; Katagiri, A.; Kiyota, K.; Honma, T.; Kamei, H.; Nariyuki, A.; Uchida, S.; Satokawa, S. Cu species incorporated into amorphous $\mathrm{ZrO}_{2}$ with high activity and selectivity in $\mathrm{CO}_{2}$-to-methanol hydrogenation. J. Phys. Chem. C 2018, 122, 5430-5442. [CrossRef]

3. Ro, I.; Liu, Y.; Ball, M.R.; Jackson, D.H.K.; Chada, J.P.; Sener, C.; Kuech, T.F.; Madon, R.J.; Huber, G.W.; Dumesic, J.A. Role of the $\mathrm{Cu}-\mathrm{ZrO}_{2}$ interfacial sites for conversion of ethanol to ethyl acetate and synthesis of methanol from $\mathrm{CO}_{2}$ and $\mathrm{H}_{2}$. ACS Catal. 2016, 6, 7040-7050. [CrossRef]

4. Bossola, F.; Scotti, N.; Somodi, F.; Coduri, M.; Evangelisti, C.; Dal Santo, V. Electron-poor copper nanoparticles over amorphous zirconia-silica as all-in-one catalytic sites for the methanol steam reforming. Appl. Catal. B Environ. 2019, 258, 118016. [CrossRef]

5. Scotti, N.; Zaccheria, F.; Evangelisti, C.; Psaro, R.; Ravasio, N. Dehydrogenative coupling promoted by copper catalysts: A way to optimise and upgrade bio-alcohols. Catal. Sci. Technol. 2017, 7, 1386-1393. [CrossRef]

6. Goeppert, A.; Czaun, M.; Jones, J.P.; Surya Prakash, G.K.; Olah, G.A. Recycling of carbon dioxide to methanol and derived products-closing the loop. Chem. Soc. Rev. 2014, 43, 7995-8048. [CrossRef] [PubMed]

7. Zaccheria, F.; Scotti, N.; Ravasio, N. The role of copper in the upgrading of bioalcohols. ChemCatChem 2018, 10, 1526-1535. [CrossRef]

8. Yuan, J.; Li, S.S.; Yu, L.; Liu, Y.M.; Cao, Y.; He, H.Y.; Fan, K.N. Copper-based catalysts for the efficient conversion of carbohydrate biomass into $\gamma$-valerolactone in the absence of externally added hydrogen. Energy Environ. Sci. 2013, 6, 3308-3313. [CrossRef]

9. Samson, K.; Sliwa, M.; Socha, R.P.; Góra-Marek, K.; Mucha, D.; Rutkowska-Zbik, D.; Paul, J.F.; Ruggiero-Mikoajczyk, M.; Grabowski, R.; Soczyński, J. Influence of $\mathrm{ZrO}_{2}$ structure and copper electronic state on activity of $\mathrm{Cu} / \mathrm{ZrO}_{2}$ catalysts in methanol synthesis from $\mathrm{CO}_{2}$. ACS Catal. 2014, 4, 3730-3741. [CrossRef]

10. Albuquerque, E.M.; Borges, L.E.P.; Fraga, M.A.; Sievers, C. Relationship between acid-base properties and the activity of $\mathrm{ZrO}_{2}$-based catalysts for the cannizzaro reaction of pyruvaldehyde to lactic acid. ChemCatChem 2017, 9, 2675-2683. [CrossRef]

11. Aramend, M.A.; Bora, V.; Marinas, M.; Urbano, F.J. Synthesis and characterization of $\mathrm{ZrO}$ as an acid-base catalyst Dehydration-dehydrogenation of propan-2-ol. J. Chem. Soc. Faraday Trans. 1997, 93, 1431-1438. [CrossRef]

12. Nagaiah, P.; Pramod, C.V.; Venkata Rao, M.; David Raju, B.; Rama Rao, K.S. Product selectivity as a function of $\mathrm{ZrO}_{2}$ phase in $\mathrm{Cu} / \mathrm{ZrO}_{2}$ catalysts in the conversion of cyclohexanol. Catal. Lett. 2018, 148, 3042-3050. [CrossRef]

13. Bonura, G.; Khassin, A.A.; Yurieva, T.M.; Cannilla, C.; Frusteri, F.; Frusteri, L. Structure control on kinetics of copper reduction in $\mathrm{Zr}$-containing mixed oxides during catalytic hydrogenation of carbon oxides to methanol. Catal. Today 2018, 342, 39-45. [CrossRef]

14. Zhou, J.; Zhang, Y.; Wu, G.; Mao, D.; Lu, G. Influence of the component interaction over $\mathrm{Cu} / \mathrm{ZrO}_{2}$ catalysts induced with fractionated precipitation method on the catalytic performance for methanol steam reforming. RSC Adv. 2016, 6, 30176-30186. [CrossRef]

15. Wu, Y.; Tan, L.; Zhang, T.; Xie, H.; Yang, G.; Tsubaki, N.; Chen, J. Effect of preparation method on $\mathrm{ZrO}_{2}$-based catalysts performance for isobutanol synthesis from syngas. Catalysts 2019, 9, 752. [CrossRef]

16. Witoon, T.; Chalorngtham, J.; Dumrongbunditkul, P.; Chareonpanich, M.; Limtrakul, J. $\mathrm{CO}_{2}$ hydrogenation to methanol over $\mathrm{Cu} / \mathrm{ZrO}_{2}$ catalysts: Effects of zirconia phases. Chem. Eng. J. 2016, 293, 327-336. [CrossRef]

17. Pakharukova, V.P.; Moroz, E.M.; Zyuzin, D.A.; Ishchenko, A.V.; Dolgikh, L.Y.; Strizhak, P.E. Structure of copper oxide species supported on monoclinic zirconia. J. Phys. Chem. C 2015, 119, 28828-28835. [CrossRef]

18. Rhodes, M.D.; Bell, A.T. The effects of zirconia morphology on methanol synthesis from $\mathrm{CO}$ and $\mathrm{H}_{2}$ over $\mathrm{Cu} / \mathrm{ZrO}_{2}$ catalysts: Part I. Steady-state studies. J. Catal. 2005, 233, 198-209. [CrossRef]

19. Sato, A.G.; Volanti, D.P.; Meira, D.M.; Damyanova, S.; Longo, E.; Bueno, J.M.C. Effect of the $\mathrm{ZrO}_{2}$ phase on the structure and behavior of supported $\mathrm{Cu}$ catalysts for ethanol conversion. J. Catal. 2013, 307, 1-17. [CrossRef] 
20. Grabowski, R.; Słoczyński, J.; Śliwa, M.; Mucha, D.; Socha, R.P.; Lachowska, M.; Skrzypek, J. Influence of polymorphic $\mathrm{ZrO}_{2}$ phases and the silver electronic state on the activity of $\mathrm{Ag} / \mathrm{ZrO}$ catalysts in the hydrogenation of $\mathrm{CO}_{2}$ to methanol. ACS Catal. 2011, 1, 266-278. [CrossRef]

21. Scotti, N.; Dangate, M.; Gervasini, A.; Evangelisti, C.; Ravasio, N.; Zaccheria, F. Unraveling the role of low coordination sites in a cu metal nanoparticle: A step toward the selective synthesis of second generation biofuels. ACS Catal. 2014, 4, 2818-2826. [CrossRef]

22. Zaccheria, F.; Scotti, N.; Marelli, M.; Psaro, R.; Ravasio, N. Unravelling the properties of supported copper oxide: Can the particle size induce acidic behaviour? Dalt. Trans. 2013, 42, 1319-1328. [CrossRef] [PubMed]

23. Teterycz, H.; Klimkiewicz, R.; Łaniecki, M. The role of Lewis acidic centers in stabilized zirconium dioxide. Appl. Catal. A Gen. 2003, 249, 313-326. [CrossRef]

24. Xia, W.; Wang, F.; Wang, L.; Wang, J.; Chen, K. Highly selective lanthanum-modified zirconia catalyst for the conversion of ethanol to propylene: A combined experimental and simulation study. Catal. Lett. 2019, 150, 1-9. [CrossRef]

25. Karapetrova, E.; Platzer, R.; Gardner, J.A.; Torne, E.; Sommers, J.A.; Evenson, W.E. Oxygen vacancies in pure tetragonal zirconia powders: Dependence on the presence of chlorine during processing. J. Am. Ceram. Soc. 2001, 84, 65-70. [CrossRef]

26. Białas, A.; Kondratowicz, T.; Drozdek, M.; Kuśtrowski, P. Catalytic combustion of toluene over copper oxide deposited on two types of yttria-stabilized zirconia. Catal. Today 2015, 257, 144-149. [CrossRef]

27. Natesakhawat, S.; Lekse, J.W.; Baltrus, J.P.; Ohodnicki, P.R.; Howard, B.H.; Deng, X.; Matranga, C. Active sites and structure-activity relationships of copper-based catalysts for carbon dioxide hydrogenation to methanol. ACS Catal. 2012, 2, 1667-1676. [CrossRef]

28. Zhao, Q.; Shih, W.H.; Chang, H.L.; Andersen, P. The effect of curing on the thermal stability of Si-doped $\mathrm{ZrO}_{2}$ powders. Appl. Catal. A Gen. 2004, 262, 215-221. [CrossRef]

29. Mayr, L.; Klötzer, B.; Zemlyanov, D.; Penner, S. Steering of methanol reforming selectivity by zirconia-copper interaction. J. Catal. 2015, 321, 123-132. [CrossRef]

30. Lam, E.; Larmier, K.; Wolf, P.; Tada, S.; Safonova, O.V.; Copéret, C. Isolated Zr surface sites on silica promote hydrogenation of $\mathrm{CO}_{2}$ to $\mathrm{CH}_{3} \mathrm{OH}$ in supported $\mathrm{Cu}$ catalysts. J. Am. Chem. Soc. 2018, 140, 10530-10535. [CrossRef]

31. Ishikawa, S.; Jones, D.R.; Iqbal, S.; Reece, C.; Morgan, D.J.; Willock, D.J.; Miedziak, P.J.; Bartley, J.K.; Edwards, J.K.; Murayama, T.; et al. Identification of the catalytically active component of Cu-Zr-O catalyst for the hydrogenation of levulinic acid to $\gamma$-valerolactone. Green Chem. 2017, 19, 225-236. [CrossRef]

32. Esposito, S.; Turco, M.; Bagnasco, G.; Cammarano, C.; Pernice, P.; Aronne, A. Highly dispersed sol-gel synthesized $\mathrm{Cu}-\mathrm{ZrO}_{2}$ materials as catalysts for oxidative steam reforming of methanol. Appl. Catal. A Gen. 2010, 372, 48-57. [CrossRef]

33. Scotti, N.; Monticelli, D.; Zaccheria, F. Dispersed copper oxide: A multifaceted tool in catalysis. Inorganica Chim. Acta 2012, 380, 194-200. [CrossRef]

34. Wang, L.C.; Liu, Q.; Chen, M.; Liu, Y.M.; Cao, Y.; He, H.Y.; Fan, K.N. Structural evolution and catalytic properties of nanostructured $\mathrm{Cu} / \mathrm{ZrO}_{2}$ catalysts prepared by oxalate gel-coprecipitation technique. J. Phys. Chem. C 2007, 111, 16549-16557. [CrossRef]

35. Aguila, G.; Guerrero, S.; Baeza, P.; Araya, P. Study of the influence of the $\mathrm{Cu} / \mathrm{Ce}$ loading ratio in the formation of highly active species on $\mathrm{ZrO}_{2}$ supported copper-ceria catalysts. Mater. Chem. Phys. 2019, 223, 666-675. [CrossRef]

36. Huber, F.; Yu, Z.; Walmsley, J.C.; Chen, D.; Venvik, H.J.; Holmen, A. Nanocrystalline Cu-Ce-Zr mixed oxide catalysts for water-gas shift: Carbon nanofibers as dispersing agent for the mixed oxide particles. Appl. Catal. B Environ. 2007, 71, 7-15. [CrossRef]

37. Liang, Q.; Wu, X.; Weng, D.; Lu, Z. Selective oxidation of soot over Cu doped ceria/ceria-zirconia catalysts. Catal. Commun. 2008, 9, 202-206. [CrossRef]

38. Shi, Z.; Tan, Q.; Wu, D. Ternary copper-cerium-zirconium mixed metal oxide catalyst for direct $\mathrm{CO}_{2}$ hydrogenation to methanol. Mater. Chem. Phys. 2018, 219, 263-272. [CrossRef]

39. Miura, H.; Nakahara, K.; Kitajima, T.; Shishido, T. Concerted functions of surface acid-base pairs and supported copper catalysts for dehydrogenative synthesis of esters from primary alcohols. ACS Omega 2017, 2, 6167-6173. [CrossRef] 
40. Gaspar, A.B.; Barbosa, F.G.; Letichevsky, S.; Appel, L.G. The one-pot ethyl acetate syntheses: The role of the support in the oxidative and the dehydrogenative routes. Appl. Catal. A Gen. 2010, 380, 113-117. [CrossRef]

41. Larmier, K.; Liao, W.C.; Tada, S.; Lam, E.; Verel, R.; Bansode, A.; Urakawa, A.; Comas-Vives, A.; Copéret, C. $\mathrm{CO}_{2}$-to-methanol hydrogenation on zirconia-supported copper nanoparticles: Reaction intermediates and the role of the metal-support interface. Angew. Chem. Int. Ed. 2017, 56, 2318-2323. [CrossRef] [PubMed]

42. Köpfle, N.; Mayr, L.; Schmidmair, D.; Bernardi, J.; Knop-Gericke, A.; Hävecker, M.; Klötzer, B.; Penner, S. A comparative discussion of the catalytic activity and $\mathrm{CO}_{2}$-selectivity of $\mathrm{Cu}-\mathrm{Zr}$ and $\mathrm{Pd}-\mathrm{Zr}$ (intermetallic) compounds in methanol steam reforming. Catalysts 2017, 7, 53. [CrossRef]

43. Orlowski, I.; Douthwaite, M.; Iqbal, S.; Hayward, J.S.; Davies, T.E.; Bartley, J.K.; Miedziak, P.J.; Hirayama, J.; Morgan, D.J.; Willock, D.J.; et al. The hydrogenation of levulinic acid to $\Gamma$-valerolactone over $\mathrm{Cu}-\mathrm{ZrO}_{2}$ catalysts prepared by a pH-gradient methodology. J. Energy Chem. 2019, 36, 15-24. [CrossRef]

44. Liu, S.; Fan, G.; Yang, L.; Li, F. Highly efficient transformation of $\Gamma$-valerolactone to valerate esters over structure-controlled copper/zirconia catalysts prepared via a reduction-oxidation route. Appl. Catal. A Gen. 2017, 543, 180-188. [CrossRef]

45. Tsai, A.P.; Kameoka, S.; Nozawa, K.; Shimoda, M.; Ishii, Y. Intermetallic: A pseudoelement for catalysis. Acc. Chem. Res. 2017, 50, 2879-2885. [CrossRef] [PubMed]

46. Xu, X.; Shuai, K.; Xu, B. Review on copper and palladium based catalysts for methanol steam reforming to produce hydrogen. Catalysts 2017, 7, 183. [CrossRef]

47. Carraro, F.; Fapohunda, A.; Paganini, M.C.; Agnoli, S. Morphology and size effect of ceria nanostructures on the catalytic performances of $\mathrm{Pd} / \mathrm{CeO}_{2}$ catalysts for methanol decomposition to syngas. ACS Appl. Nano Mater. 2018, 1, 1492-1501. [CrossRef]

48. Khzouz, M.; Gkanas, E.I.; Du, S.; Wood, J. Catalytic performance of $\mathrm{Ni}-\mathrm{Cu} / \mathrm{Al}_{2} \mathrm{O}_{3}$ for effective syngas production by methanol steam reforming. Fuel 2018, 232, 672-683. [CrossRef]

49. Ali, K.A.; Abdullah, A.Z.; Mohamed, A.R. Recent development in catalytic technologies for methanol synthesis from renewable sources: A critical review. Renew. Sustain. Energy Rev. 2015, 44, 508-518. [CrossRef]

50. Din, I.U.; Shaharun, M.S.; Alotaibi, M.A.; Alharthi, A.I.; Naeem, A. Recent developments on heterogeneous catalytic $\mathrm{CO}_{2}$ reduction to methanol. J. $\mathrm{CO}_{2}$ Util. 2019, 34, 20-33. [CrossRef]

51. Jadhav, S.G.; Vaidya, P.D.; Bhanage, B.M.; Joshi, J.B. Catalytic carbon dioxide hydrogenation to methanol: A review of recent studies. Chem. Eng. Res. Des. 2014, 92, 2557-2567. [CrossRef]

52. Li, K.; Chen, J.G. $\mathrm{CO}_{2}$ Hydrogenation to methanol over $\mathrm{ZrO}_{2}$-containing catalysts: Insights into $\mathrm{ZrO}_{2}$ induced synergy. ACS Catal. 2019, 9, 7840-7861. [CrossRef]

53. Sá, S.; Silva, H.; Brandão, L.; Sousa, J.M.; Mendes, A. Catalysts for methanol steam reforming-A review. Appl. Catal. B Environ. 2010, 99, 43-57. [CrossRef]

54. Yong, S.T.; Ooi, C.W.; Chai, S.P.; Wu, X.S. Review of methanol reforming-Cu-based catalysts, surface reaction mechanisms, and reaction schemes. Int. J. Hydrogen Energy 2013, 38, 9541-9552. [CrossRef]

55. Kubacka, A.; Fernández-García, M.; Martínez-Arias, A. Catalytic hydrogen production through WGS or steam reforming of alcohols over $\mathrm{Cu}, \mathrm{Ni}$ and Co catalysts. Appl. Catal. A Gen. 2016, 518, 2-17. [CrossRef]

56. Tsoncheva, T.; Genova, I.; Dimitrov, M.; Sarcadi-Priboczki, E.; Venezia, A.M.; Kovacheva, D.; Scotti, N.; dal Santo, V. Nanostructured copper-zirconia composites as catalysts for methanol decomposition. Appl. Catal. B Environ. 2015, 165, 599-610. [CrossRef]

57. Liu, P.; Yang, Y.; White, M.G. Theoretical perspective of alcohol decomposition and synthesis from $\mathrm{CO}_{2}$ hydrogenation. Surf. Sci. Rep. 2013, 68, 233-272. [CrossRef]

58. Ratnasamy, C.; Wagner, J. Water gas shift catalysis. Catal. Rev. Sci. Eng. 2009, 51, 325-440. [CrossRef]

59. Gokhale, A.A.; Dumesic, J.A.; Mavrikakis, M. On the mechanism of low-temperature water gas shift reaction on copper. J. Am. Chem. Soc. 2008, 130, 1402-1414. [CrossRef]

60. Kattel, S.; Yan, B.; Yang, Y.; Chen, J.G.; Liu, P. Optimizing binding energies of key intermediates for $\mathrm{CO}_{2}$ hydrogenation to methanol over oxide-supported copper. J. Am. Chem. Soc. 2016, 138, 12440-12450. [CrossRef]

61. Fisher, I.A.; Bell, A.T. A mechanistic study of methanol decomposition over $\mathrm{Cu} / \mathrm{SiO}_{2}, \mathrm{ZrO}_{2} / \mathrm{SiO}_{2}$, and $\mathrm{Cu} / \mathrm{ZrO}_{2} / \mathrm{SiO}_{2}$. J. Catal. 1999, 184, 357-376. [CrossRef]

62. Fisher, I.A.; Bell, A.T. In-situ infrared study of methanol synthesis from $\mathrm{H}_{2} / \mathrm{CO}_{2}$ over $\mathrm{Cu} / \mathrm{SiO} \mathrm{O}_{2}$ and $\mathrm{Cu} / \mathrm{ZrO}_{2} / \mathrm{SiO}_{2}$. J. Catal. 1997, 172, 222-237. [CrossRef] 
63. Prieto, G.; Zečević, J.; Friedrich, H.; De Jong, K.P.; De Jongh, P.E. Towards stable catalysts by controlling collective properties of supported metal nanoparticles. Nat. Mater. 2013, 12, 34-39. [CrossRef] [PubMed]

64. Matsumura, Y. Stabilization of $\mathrm{Cu} / \mathrm{ZnO} / \mathrm{ZrO}_{2}$ catalyst for methanol steam reforming to hydrogen by coprecipitation on zirconia support. J. Power Sources 2013, 238, 109-116. [CrossRef]

65. Matsumura, Y.; Ishibe, $\mathrm{H}$. High temperature steam reforming of methanol over $\mathrm{Cu} / \mathrm{ZnO} / \mathrm{ZrO}_{2}$ catalysts. Appl. Catal. B Environ. 2009, 91, 524-532. [CrossRef]

66. Morterra, C.; Giamello, E.; Orio, L.; Volante, M. Formation and reactivity of $\mathrm{Zr}^{3+}$ centers at the surface of vacuum-activated monoclinic zirconia. J. Phys. Chem. 1990, 94, 3111-3116. [CrossRef]

67. Jung, K.D.; Bell, A.T. Role of hydrogen spillover in methanol synthesis over $\mathrm{Cu} / \mathrm{ZrO}_{2}$. J. Catal. 2000, 193, 207-223. [CrossRef]

68. Ruano, D.; Cored, J.; Azenha, C.; Pérez-Dieste, V.; Mendes, A.; Mateos-Pedrero, C.; Concepción, P. Dynamic structure and subsurface oxygen formation of a working copper catalyst under methanol steam reforming conditions: An in situ time-resolved spectroscopic study. ACS Catal. 2019, 9, 2922-2930. [CrossRef]

69. Yang, H.; Chen, Y.; Cui, X.; Wang, G.; Cen, Y.; Deng, T.; Yan, W.; Gao, J.; Zhu, S.; Olsbye, U.; et al. A highly stable copper-based catalyst for clarifying the catalytic roles of $\mathrm{Cu}^{0}$ and $\mathrm{Cu}^{+}$species in methanol dehydrogenation. Angew. Chem. Int. Ed. 2018, 57, 1836-1840. [CrossRef]

70. Stefanovich, E.V.; Shluger, A.L.; Catlow, C.R.A. Theoretical study of the stabilization of cubic-phase $\mathrm{ZrO}_{2}$ by impurities. Phys. Rev. B 1994, 49, 11560-11571. [CrossRef]

71. Yao, C.Z.; Wang, L.C.; Liu, Y.M.; Wu, G.S.; Cao, Y.; Dai, W.L.; He, H.Y.; Fan, K.N. Effect of preparation method on the hydrogen production from methanol steam reforming over binary $\mathrm{Cu} / \mathrm{ZrO}_{2}$ catalysts. Appl. Catal. A Gen. 2006, 297, 151-158. [CrossRef]

72. Pokrovski, K.A.; Rhodes, M.D.; Bell, A.T. Effects of cerium incorporation into zirconia on the activity of $\mathrm{Cu} / \mathrm{ZrO}_{2}$ for methanol synthesis via $\mathrm{CO}$ hydrogenation. J. Catal. 2005, 235, 368-377. [CrossRef]

73. Semelsberger, T.A.; Borup, R.L.; Greene, H.L. Dimethyl ether (DME) as an alternative fuel. J. Power Sources 2006, 156, 497-511. [CrossRef]

74. Frusteri, F.; Bonura, G.; Cannilla, C.; Drago Ferrante, G.; Aloise, A.; Catizzone, E.; Migliori, M.; Giordano, G. Stepwise tuning of metal-oxide and acid sites of CuZnZr-MFI hybrid catalysts for the direct DME synthesis by $\mathrm{CO}_{2}$ hydrogenation. Appl. Catal. B Environ. 2015, 176-177, 522-531. [CrossRef]

75. Bonura, G.; Migliori, M.; Frusteri, L.; Cannilla, C.; Catizzone, E.; Giordano, G.; Frusteri, F. Acidity control of zeolite functionality on activity and stability of hybrid catalysts during DME production via $\mathrm{CO}_{2}$ hydrogenation. J. $\mathrm{CO}_{2}$ Util. 2018, 24, 398-406. [CrossRef]

76. Tada, S.; Satokawa, S. Effect of Ag loading on $\mathrm{CO}_{2}$-to-methanol hydrogenation over $\mathrm{Ag} / \mathrm{CuO} / \mathrm{ZrO} 2$. Catal. Commun. 2018, 113, 41-45. [CrossRef]

77. Tada, S.; Watanabe, F.; Kiyota, K.; Shimoda, N.; Hayashi, R.; Takahashi, M.; Nariyuki, A.; Igarashi, A.; Satokawa, S. Ag addition to $\mathrm{CuO}-\mathrm{ZrO}_{2}$ catalysts promotes methanol synthesis via $\mathrm{CO}_{2}$ hydrogenation. J. Catal. 2017, 351, 107-118. [CrossRef]

78. Oguchi, H.; Kanai, H.; Utani, K.; Matsumura, Y.; Imamura, $\mathrm{S} . \mathrm{Cu}_{2} \mathrm{O}$ as active species in the steam reforming of methanol by $\mathrm{CuO} / \mathrm{ZrO}_{2}$ catalysts. Appl. Catal. A Gen. 2005, 293, 64-70. [CrossRef]

79. Mastalir, A.; Frank, B.; Szizybalski, A.; Soerijanto, H.; Deshpande, A.; Niederberger, M.; Schomäcker, R.; Schlögl, R.; Ressler, T. Steam reforming of methanol over $\mathrm{Cu} / \mathrm{ZrO}_{2} / \mathrm{CeO}_{2}$ catalysts: A kinetic study. J. Catal. 2005, 230, 464-475. [CrossRef]

80. Grabow, L.C.; Mavrikakis, M. Mechanism of methanol synthesis on cu through $\mathrm{CO}_{2}$ and $\mathrm{CO}$ hydrogenation. ACS Catal. 2011, 1, 365-384. [CrossRef]

81. Tada, S.; Kayamori, S.; Honma, T.; Kamei, H.; Nariyuki, A.; Kon, K.; Toyao, T.; Shimizu, K.I.; Satokawa, S. Design of interfacial sites between $\mathrm{Cu}$ and amorphous $\mathrm{ZrO}_{2}$ dedicated to $\mathrm{CO}_{2}$-to-methanol hydrogenation. ACS Catal. 2018, 8, 7809-7819. [CrossRef]

82. Lam, E.; Larmier, K.; Tada, S.; Wolf, P.; Safonova, O.V.; Copéret, C. $\mathrm{Zr}(\mathrm{IV})$ surface sites determine $\mathrm{CH}_{3} \mathrm{OH}$ formation rate on $\mathrm{Cu} / \mathrm{ZrO}_{2} / \mathrm{SiO}_{2}-\mathrm{CO}_{2}$ hydrogenation catalysts. Chin. J. Catal. 2019, 40, 1741-1748. [CrossRef]

83. Wu, G.; Sun, Y.; Li, Y.W.; Jiao, H.; Xiang, H.W.; Xu, Y. The nature of $\mathrm{Cu} / \mathrm{ZrO}_{2}$ catalyst: Experimental and theoretical studies. J. Mol. Struct. THEOCHEM 2003, 626, 287-293. [CrossRef]

84. Tang, Q.L.; Liu, Z.P. Identification of the active $\mathrm{Cu}$ phase in the water-gas shift reaction over $\mathrm{Cu} / \mathrm{ZrO}_{2}$ from first principles. J. Phys. Chem. C 2010, 114, 8423-8430. [CrossRef] 
85. Polierer, S.; Jelic, J.; Pitter, S.; Studt, F. On the reactivity of the $\mathrm{Cu} / \mathrm{ZrO}_{2}$ system for the hydrogenation of $\mathrm{CO}_{2}$ to methanol: A density functional theory study. J. Phys. Chem. C 2019, 123, 26904-26911. [CrossRef]

86. Wang, W.; Wang, S.; Ma, X.; Gong, J. Recent advances in catalytic hydrogenation of carbon dioxide. Chem. Soc. Rev. 2011, 40, 3703-3727. [CrossRef]

87. Tang, Q.L.; Hong, Q.J.; Liu, Z.P. $\mathrm{CO}_{2}$ fixation into methanol at $\mathrm{Cu} / \mathrm{ZrO}_{2}$ interface from first principles kinetic Monte Carlo. J. Catal. 2009, 263, 114-122. [CrossRef]

88. Kattel, S.; Liu, P.; Chen, J.G. Tuning selectivity of $\mathrm{CO}_{2}$ hydrogenation reactions at the metal/oxide interface. J. Am. Chem. Soc. 2017, 139, 9739-9754. [CrossRef]

89. Tada, S.; Larmier, K.; Büchel, R.; Copéret, C. Methanol synthesis: Via $\mathrm{CO}_{2}$ hydrogenation over $\mathrm{CuO}-\mathrm{ZrO}_{2}$ prepared by two-nozzle flame spray pyrolysis. Catal. Sci. Technol. 2018, 8, 2056-2060. [CrossRef]

90. Lin, S.; Xie, D.; Guo, H. Methyl formate pathway in methanol steam reforming on copper: Density functional calculations. ACS Catal. 2011, 1, 1263-1271. [CrossRef]

91. Frank, B.; Jentoft, F.C.; Soerijanto, H.; Kröhnert, J.; Schlögl, R.; Schomäcker, R. Steam reforming of methanol over copper-containing catalysts: Influence of support material on microkinetics. J. Catal. 2007, 246, 177-192. [CrossRef]

92. Liao, P.H.; Yang, H.M. Preparation of catalyst Ni-Cu/CNTs by chemical reduction with formaldehyde for steam reforming of methanol. Catal. Lett. 2008, 121, 274-282. [CrossRef]

93. Ribeirinha, P.; Mateos-pedrero, C.; Boaventura, M.; Sousa, J.; Mendes, A. CuO/ZnO/ $\mathrm{Ga}_{2} \mathrm{O}_{3}$ catalyst for low temperature MSR reaction: Synthesis, characterization and kinetic model. Appl. Catal. B Environ. 2018, 221, 371-379. [CrossRef]

94. Azenha, C.S.R.; Mateos-Pedrero, C.; Queirós, S.; Concepción, P.; Mendes, A. Innovative $\mathrm{ZrO}_{2}$-supported $\mathrm{CuPd}$ catalysts for the selective production of hydrogen from methanol steam reforming. Appl. Catal. B Environ. 2017, 203, 400-407. [CrossRef]

95. Baneshi, J.; Haghighi, M.; Jodeiri, N.; Abdollahifar, M.; Ajamein, H. Homogeneous precipitation synthesis of $\mathrm{CuO}-\mathrm{ZrO}_{2}-\mathrm{CeO}_{2}-\mathrm{Al}_{2} \mathrm{O}_{3}$ nanocatalyst used in hydrogen production via methanol steam reforming for fuel cell applications. Energy Convers. Manag. 2014, 87, 928-937. [CrossRef]

96. Das, D.; Llorca, J.; Dominguez, M.; Colussi, S.; Trovarelli, A.; Gayen, A. Methanol steam reforming behavior of copper impregnated over $\mathrm{CeO}_{2}-\mathrm{ZrO}_{2}$ derived from a surfactant assisted coprecipitation route. Int. J. Hydrogen Energy 2015, 40, 10463-10479. [CrossRef]

97. Deshmane, V.G.; Abrokwah, R.Y.; Kuila, D. Synthesis of stable Cu-MCM-41 nanocatalysts for $\mathrm{H}_{2}$ production with high selectivity via steam reforming of methanol. Int. J. Hydrogen Energy 2015, 40, 10439-10452. [CrossRef]

98. Lytkina, A.A.; Orekhova, N.V.; Ermilova, M.M.; Yaroslavtsev, A.B. The influence of the support composition and structure $\left(\mathrm{MXZr}_{1}-\mathrm{XO}_{2}-\Delta\right)$ of bimetallic catalysts on the activity in methanol steam reforming. Int. J. Hydrogen Energy 2018, 43, 198-207. [CrossRef]

99. Ritzkopf, I.; Vukojević, S.; Weidenthaler, C.; Grunwaldt, J.D.; Schüth, F. Decreased CO production in methanol steam reforming over $\mathrm{Cu} / \mathrm{ZrO}_{2}$ catalysts prepared by the microemulsion technique. Appl. Catal. A Gen. 2006, 302, 215-223. [CrossRef]

100. Wu, G.S.; Mao, D.S.; Lu, G.Z.; Cao, Y.; Fan, K.N. The role of the promoters in Cu based catalysts for methanol steam reforming. Catal. Lett. 2009, 130, 177-184. [CrossRef]

101. Sun, J.; Wang, Y. Recent advances in catalytic conversion of ethanol to chemicals. ACS Catal. 2014, 4, 1078-1090. [CrossRef]

102. Sheldon, R.A. Green and sustainable manufacture of chemicals from biomass: State of the art. Green Chem. 2014, 16, 950-963. [CrossRef]

103. Bankar, S.B.; Survase, S.A.; Ojamo, H.; Granström, T. Biobutanol: The outlook of an academic and industrialist. RSC Adv. 2013, 3, 24734-24757. [CrossRef]

104. Rajesh Kumar, B.; Saravanan, S. Use of higher alcohol biofuels in diesel engines: A review. Renew. Sustain. Energy Rev. 2016, 60, 84-115. [CrossRef]

105. Moromi, S.K.; Hakim Siddiki, S.M.A.; Ali, M.A.; Kon, K.; Shimizu, K.I. Acceptorless dehydrogenative coupling of primary alcohols to esters by heterogeneous Pt catalysts. Catal. Sci. Technol. 2014, 4, 3631-3635. [CrossRef] 
106. Nguyen, D.H.; Trivelli, X.; Capet, F.; Swesi, Y.; Favre-Réguillon, A.; Vanoye, L.; Dumeignil, F.; Gauvin, R.M. Deeper mechanistic insight into Ru pincer-mediated acceptorless dehydrogenative coupling of alcohols: Exchanges, intermediates, and deactivation species. ACS Catal. 2018, 8, 4719-4734. [CrossRef]

107. Petrolini, D.D.; Cassinelli, W.H.; Pereira, C.A.; Urquieta-González, E.A.; Santilli, C.V.; Martins, L. Ethanol dehydrogenative reactions catalyzed by copper supported on porous Al-Mg mixed oxides. RSC Adv. 2019, 9, 3294-3302. [CrossRef]

108. Inui, K.; Kurabayashi, T.; Sato, S. Direct synthesis of ethyl acetate from ethanol carried out under pressure. J. Catal. 2002, 212, 207-215. [CrossRef]

109. Inui, K.; Kurabayashi, T.; Sato, S.; Ichikawa, N. Effective formation of ethyl acetate from ethanol over Cu-Zn-Zr-Al-O catalyst. J. Mol. Catal. A Chem. 2004, 216, 147-156. [CrossRef]

110. Sato, A.G.; Volanti, D.P.; De Freitas, I.C.; Longo, E.; Bueno, J.M.C. Site-selective ethanol conversion over supported copper catalysts. Catal. Commun. 2012, 26, 122-126. [CrossRef]

111. Liu, X.; Bai, S.; Zhuang, H.; Yan, Z. Preparation of $\mathrm{Cu} / \mathrm{ZrO}_{2}$ catalysts for methanol synthesis from $\mathrm{CO}_{2} / \mathrm{H}_{2}$. Front. Chem. Sci. Eng. 2012, 6, 47-52. [CrossRef]

112. Basahel, S.; Mokhtar, M.; Alsharaeh, E.; Ali, T.; Mahmoud, H.; Narasimharao, K. Physico-chemical and catalytic properties of mesoporous $\mathrm{CuO}-\mathrm{ZrO}_{2}$ catalysts. Catalysts 2016, 6, 57. [CrossRef]

113. Liu, Z.; Amiridis, M.D.; Chen, Y. Characterization of $\mathrm{CuO}$ supported on tetragonal $\mathrm{ZrO}_{2}$ catalysts for $\mathrm{N}_{2} \mathrm{O}$ decomposition to $\mathrm{N}_{2}$. J. Phys. Chem. B 2005, 109, 1251-1255. [CrossRef] [PubMed]

114. Liu, J.; Shi, J.; He, D.; Zhang, Q.; Wu, X.; Liang, Y.; Zhu, Q. Surface active structure of ultra-fine Cu/ZrO 2 catalysts used for the $\mathrm{CO}_{2}+\mathrm{H}_{2}$ to methanol reaction. Appl. Catal. A Gen. 2001, 218, 113-119. [CrossRef]

115. Breen, J.P.; Ross, J.R.H. Methanol reforming for fuel-cell applications: Development of zirconia-containing Cu-Zn-Al catalysts. Catal. Today 1999, 51, 521-533. [CrossRef]

116. Lee, J.F.; Zheng, F.S.; Chang, J.R. Structural investigation of solid-acid-promoted Pd/SDB catalysts for ethyl acetate production from ethanol. J. Phys. Chem. B 2002, 105, 3400-3404. [CrossRef]

117. Hayashi, T.; Inagaki, T.; Itayama, N.; Baba, H. Selective oxidation of alcohol over supported gold catalysts: Methyl glycolate formation from ethylene glycol and methanol. Catal. Today 2006, 117, 210-213. [CrossRef]

118. Sánchez, A.B.; Homs, N.; Fierro, J.L.G.; De La Piscina, P.R. New supported Pd catalysts for the direct transformation of ethanol to ethyl acetate under medium pressure conditions. Catal. Today 2005, 107-108, 431-435. [CrossRef]

119. Hakim Siddiki, S.M.A.; Toyao, T.; Shimizu, K.I. Acceptorless dehydrogenative coupling reactions with alcohols over heterogeneous catalysts. Green Chem. 2018, 20, 2933-2952. [CrossRef]

120. Ichikawa, N.; Sato, S.; Takahashi, R.; Sodesawa, T.; Inui, K. Dehydrogenative cyclization of 1,4-butanediol over copper-based catalyst. J. Mol. Catal. A Chem. 2004, 212, 197-203. [CrossRef]

121. Inui, K.; Kurabayashi, T.; Sato, S. Direct synthesis of ethyl acetate from ethanol over Cu-Zn-Zr-Al-O catalyst. Appl. Catal. A Gen. 2002, 237, 53-61. [CrossRef]

122. Balla, P.; Perupogu, V.; Vanama, P.K.; Komandur, V.R.C. Hydrogenation of biomass-derived levulinic acid to $\gamma$-valerolactone over copper catalysts supported on $\mathrm{ZrO}_{2}$. J. Chem. Technol. Biotechnol. 2016, 91, 769-776. [CrossRef]

123. Du, X.L.; Bi, Q.Y.; Liu, Y.M.; Cao, Y.; He, H.Y.; Fan, K.N. Tunable copper-catalyzed chemoselective hydrogenolysis of biomass-derived $\gamma$-valerolactone into 1,4-pentanediol or 2-methyltetrahydrofuran. Green Chem. 2012, 14, 935-939. [CrossRef]

124. Zhang, Y.; Fan, G.; Yang, L.; Li, F. Efficient conversion of furfural into cyclopentanone over high performing and stable $\mathrm{Cu} / \mathrm{ZrO}_{2}$ catalysts. Appl. Catal. A Gen. 2018, 561, 117-126. [CrossRef]

125. Jones, D.R.; Iqbal, S.; Ishikawa, S.; Reece, C.; Thomas, L.M.; Miedziak, P.J.; Morgan, D.J.; Edwards, J.K.; Bartley, J.K.; Willock, D.J.; et al. The conversion of levulinic acid into $\gamma$-valerolactone using $\mathrm{Cu}_{-} \mathrm{ZrO}_{2}$ catalysts. Catal. Sci. Technol. 2016, 6, 6022-6030. [CrossRef]

126. Yang, Y.; Xu, X.; Zou, W.; Yue, H.; Tian, G.; Feng, S. Transfer hydrogenation of methyl levulinate into gamma-valerolactone, 1,4-pentanediol, and 1-pentanol over $\mathrm{Cu}-\mathrm{ZrO}_{2}$ catalyst under solvothermal conditions. Catal. Commun. 2016, 76, 50-53. [CrossRef]

127. Gilkey, M.J.; Xu, B. Heterogeneous catalytic transfer hydrogenation as an effective pathway in biomass upgrading. ACS Catal. 2016, 6, 1420-1436. [CrossRef]

128. Wang, D.; Astruc, D. The golden age of transfer hydrogenation. Chem. Rev. 2015, 115, 6621-6686. [CrossRef] 
129. Gonell, F.; Boronat, M.; Corma, A. Structure-reactivity relationship in isolated Zr sites present in Zr-zeolite and $\mathrm{ZrO}_{2}$ for the Meerwein-Ponndorf-Verley reaction. Catal. Sci. Technol. 2017, 7, 2865-2873. [CrossRef]

130. Harianawala, H.; Kheur, M.; Bal, A. Biocompatibility of zirconia. J. Adv. Med. Dent. Sci. Res. 2016, 4, 35-39.

131. Zhu, N.; Zhang, A.; Wang, Q.; He, P.; Fang, Y. Electrochemical detection of DNA hybridization using methylene blue and electro-deposited zirconia thin films on gold electrodes. Anal. Chim. Acta 2004, 510, 163-168. [CrossRef]

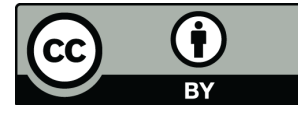

(C) 2020 by the authors. Licensee MDPI, Basel, Switzerland. This article is an open access article distributed under the terms and conditions of the Creative Commons Attribution (CC BY) license (http://creativecommons.org/licenses/by/4.0/). 